\title{
Trans-Sectual Identity
}

\section{Materials for the Study of the Praśnottararatnamālikā, a Hindu/Jaina/Buddhist Catechism (I)}

\author{
Jonathan A. Silk \\ Leiden University \\ J.A.Silk@hum.leidenuniv.nl \\ with Péter-Dániel Szántó
}

All Souls College, Oxford University, and Leiden University

\begin{abstract}
The Praśnottararatnamālikā is a small tract containing 62 questions, paired with their answers. It is extraordinary that this text has been transmitted within Hindu, Jaina and Buddhist traditions, in Sanskrit, Prakrit and Tibetan, variously attributed to different authors. The present study examines what is known of the text, which from early on drew the attention of modern scholars, and presents editions of its Sanskrit and Tibetan versions, along with a translation and annotations.
\end{abstract}

\section{Keywords}

Praśnottararatnamālikā - Sanskrit literature - catechism - Tibetan literature - Jainism - Buddhism - Hinduism

The Praśnottararatnamālikā is a small tract of some 27 or so verses containing 62 or so questions, paired with their answers. In terms of its content, the text is unremarkable, even banal, although some verses are, it is true, rather nice. What is, however, extraordinary is that the text has been transmitted within Hindu, Jaina and Buddhist traditions, in Sanskrit, Prakrit and Tibetan. The correspondences between these versions are extremely strong, and it is obvious that we have to do not with a set of closely related texts but indeed with one and the same text, differentially transmitted with, unsurprisingly, various attributions of authorship. The study below examines what is known of the text, 
which from early on drew the attention of modern scholars, and presents editions of its Sanskrit and Tibetan versions, along with a translation. ${ }^{1}$

\section{$1 \quad$ History of Study}

The first modern scholarly notice of our text took place quite early, in $185^{8}$, with its publication in Tibetan by Anton Schiefner. ${ }^{2}$ He knew the text under the title Vimalapraśnottararatnamālā, under which it is catalogued in Tibetan sources (see below), and presented it in Tibetan, with a German translation. This was followed in 1867 by Philippe-Edouard Foucaux's bilingual edition, in which he presented both the Sanskrit text and its Tibetan translation, along with a French rendering. ${ }^{3}$ It may be the fact that some manuscripts punctuate the text according to its question-answer format that led Foucaux, despite the metrical shape of the Tibetan translation, to print the text as if it were in prose, separating out the individual questions and answers. ${ }^{4}$ This oversight was

1 The Prakrit text will be published separately by Melinda Fodor.

This study profited in the first place from the presence in Leiden of Csaba Dezső, resident as part of the ERC-funded research project Asia Beyond Boundaries (6o9823), and Melinda Fodor, here through the auspices of the Gonda Funds of the Netherlands Royal Academy. The text was also read along with a number of my students and others who contributed to our understanding. Kristen de Joseph kindly deciphered the Tilagari manuscript; I am most grateful to Usha Colas Chauhan for her careful transcription of the important manuscript D, written in Telugu script. Among those who participated in our reading group were Channa Li, Yixiu Jiang, Gregory Forgues, Christopher Handy, and Shinko Suzuki. I was later able to revise extensively thanks to the extremely generous help of Peter Szántó. Madhav Deshpande during a visit to Leiden kindly offered valuable hints which, again, assisted my understanding. Finally, a number of corrections were kindly suggested by Jens-Uwe Hartmann, an even greater number by Harunaga Isaacson, and (at least!) one excellent suggestion by Peter Bisschop.

2 It is perhaps actually mentioned, as a Jaina work either in his possession or that of the Library of the Sanscrit College of Calcutta, for the first time by Wilson 1832: 244, with the spelling Prishnottara Retnamálá.

3 Foucaux in fact published the text twice; bibliographies imply that its first publication in the Mémoires de l'Académie des Stanislas of 1867 was simply reproduced in the same year by Maisonneuve, but this is not true. Not only does the second publication include the (handwritten) Tibetan text, and have 7 pages of "Additions et corrections," it also has at least one change in its text, discussed in the next note. It is this Maisonneuve publication to which Garrez referred (see below).

4 There is a more than curious comment in the Mémoires version of Foucaux's edition, on page 57: "Nous avons donné d' abord le texte sanskrit en séparant chaque demande suivie de la réponse, avec un numéro d' ordre, comme l' a fait l'édition de Bombay. Pour qu' on retrouve ce texte sous sa véritable forme, c'est-à-dire en stances, il est répété tout entier à la suite de 
almost immediately noticed by a scholar whose work seems to have entirely escaped all subsequent students of the text, namely (Pierre-)Gustave Garrez, whose review published in the same year as Foucaux's edition was able to correct many errors. ${ }^{5}$ Among other things, he correctly identified the text as written in $\bar{a} r y \bar{a}$ meter. This same identification was again made by Albrecht Weber in the next year, in 1868, apparently without an awareness of Garrez's review. Weber printed the text in metrical form and translated it into German, adding (again, with German translation) another very similar tract, this too having been noticed by Garrez, the Praśnottaramā $\overline{l a}$ attributed to Śuka Yatīndra, ${ }^{6}$ a work which had, as both Weber and Garrez knew, already been printed in Sanskrit and translated into English in 1847 by John Christian. ${ }^{7}$ (I refer to some

la traduction." The edition is not in fact followed by any repetition of the text, metrical or otherwise. Moreover, this entire paragraph is replaced in the otherwise identical Maisonneuve publication (p. 8) with the following: "En comparant la version tibétaine qui est en vers, au texte sanskrit qui est en prose, on voit qu' elle est beaucoup plus développée, ce qui était inévitable à cause de l' exigence de la mesure. Ceci porterait à croire que le nom donné dans la traduction tibétaine à l'auteur de la Guirlande des demandes et des réponses n'est que celui du poëte qui a traduit en vers la prose sanskrite." It is very hard to understand this, unless it might be that Foucaux, failing to identify the metre, precipitously concluded, sometime before its republication along with the Tibetan text, that the text must after all be in prose.

5 Garrez is not a fan of Foucaux's translation. He concludes his review with the following (1867: 506-507), commenting on an additional note of Foucaux (in the Maisonneuve edition) to item 50: "La version tibétaine présentant, au dire de l' auteur, un sens différent de celui que donne le sanskrit, il propose un changement dans ce dernier tèxte, et en tire une traduction plus conforme, à son avis, au tibétain. Cette traduction est naturellement fausse, puisqu' elle s'appuie, d'un côté, sur une transposition contraire au mètre, et, de l' autre, sur l' hypothèse inadmissible qui vidheyâ peut avoir le sens de: à qui il faut donner. Mais je crois trouver dans cette note l'explication de cetter singulière persistance à ne pas se servir du dictionnaire sanskrit. M. Foucaux a interprété le sanskrit au moyen du tibétain. Le sens que lui a donné la traduction tibétaine, il a voulu le retrouver dans le sanskrit; on ne saurait se rendre compte d'une autre manière des fautes si graves et si nombreuses qu'il a commises dans l'interprétation d'un texte si court et si simple." I would simply add that while the text is indeed short, it is perhaps not everywhere as simple as Garrez found it.

6 The only reference to this figure in Flügel \& Krümpelmann 2016: 824 b is precisely to Christian 1847. The colophon in the manuscript recorded at http://catalogue-old.ngmcp.uni-hamburg .de/mediawiki/index.php/A_384-18_Pra\%C5\%9Bnottar\%C4\%AB reads: iti śriśukayatìmdraviracitā praśnottaramālā samāptā.

7 Bhattacarya in 1929, who identifies an entry in a manuscript catalogue as this text, knows Schiefner's and Foucaux's editions, and then, apparently independently, again identifies the text as in āryā metre. He refers to an 1848 Catalogue of the Sanskrit Manuscripts in the Fort William [sic] by James Prinsep, in which the text is "ascribed to one Guru Asitapața or Guru Jaina Asitapața." I have been unable to locate any such catalogue of Prinsep. However, Foucaux based his own text on a copy of manuscript 2628 of Fort William, which could be the 
parallels with this text in the edition and translation below.) Late in the 19th c. several scholars discussed aspects of the Praśnottararatnamälikā, especially with regard to its authorship and sectarian location (see below). Just at the end of the century, in 1898, Paolo Emilio Pavolini published a "Prakrit recension" of the text, reedited in the forthcoming article by Melinda Fodor.

After the early rush of interest in the 19th c., the text appears to have fallen out of the sight of scholars for some decades. It was only in 1935 that Kanakura Enshō again paid it particular attention, offering editions in, once again, Sanskrit and Tibetan, with Japanese translation, and a discussion of their mutual relation. Although he was aware of the Prakrit version, he did not include it in his edition. This study has subsequently not been much noticed, and seems to have remained entirely unknown outside of Japan. ${ }^{8}$ In the twentieth century, it is perhaps Suniti Kumar Pathak who paid most attention to the text, but there is, in essence, nothing new in his study. ${ }^{9}$

I am not sure when the first modern publication of the Sanskrit Praśnottararatnamālikā took place, and it may have been that of Foucaux. However, especially since it is considered by some to be a work of Śankara, it has appeared in any number of collections, and been repeatedly translated both in print and on websites (and lectured upon extensively on Youtube, also in English). Foucaux refers to an Indian lithograph of 186o, but no further information is available. The earliest Indian publication of which I am aware is that in the Kāvyamālā series published by the renowned Nirnaya-sāgara press in 1890 ( $\mathrm{K}$ below), and it has subsequently appeared in multiple editions of the Collected Works of Śankkara (S below), the latter version being, as I would maintain, significantly extended, ${ }^{10}$ containing as it does not 27 but rather 67 verses. With the exception of the edition in the Kāvyamālā series, in the sources available to me no attempt is made to clarify the sources upon which the Indian

same. I do not know if either of the two Paris manuscripts used in the present edition is that which served as the base of Foucaux's edition.

8 This is a pity since, although I cannot always agree with his conclusions, Kanakura was a thoughtful and careful scholar, and his ideas are certainly worthy of serious consideration. However, his Japanese is slightly archaic, and this may have contributed to the lack of attention his work is paid these days.

9 The pages in Pathak 1974: 25-32 reproduce his 1958a article, without its edition or sample of the text in translation, but adding a few remarks on the Tibetan translator. Mention might also be made here of Torricelli 1993 .

10 Kanakura 1935: 405, 416-417, discussed this question concerning the addition of the further 40 verses, in which, as he points out, Vedantin content is found, otherwise absent in the portion of the text edited here, and concluded as I have that these verses were added subsequent to the establishment of the core of the text. 
editions are based. What is more, it seems that the editions of Weber, Kanakura and Pathak exclusively base themselves on the text as printed by Foucaux. ${ }^{11}$ If nothing else, the present publication is based on a somewhat wider evidentiary basis.

A fair number of manuscripts of the text are documented, ${ }^{12}$ among which the edition here is based on the following sources:

C: Chunilal Gandhi Vidyabhavan, Surat, Shastri Dinamanishankara collection, sDPBO213, 10.5 × 4.5". 2 folios. Nāgarī. [https://archive.org/details/ prashnottararatnamalika-CGV-SDPB-o213]. [Note that K's manuscript kha is also from Surat.]

D: Cod.Palmbl. I 27, in Hamburg (Staatsbibliothek). Janert and Poti 1975 item 1413. Folia numbered $42^{\mathrm{r}}-43^{\mathrm{r}}$ of the MS catalogued in the same collection as $1215,3.7 \times 35 \mathrm{~cm}, 6 \sim 8$ lines per side, in Telugu script. The 11th of 15 works in the manuscript. The version here has an idiosyncratic ordering of verses. After verse 7 the ordering is as follows: D 8 $=11 \mathrm{~cd}+12 \mathrm{ab} ; 9$ = 12cd+10ab; $10=8 ; 11=9 \mathrm{ab}+11 \mathrm{ab} ; 12$ = 10cd $+14 \mathrm{ab} ; 13=$ $14 c d+17 a b ; 14=16 c d+17 a b ; 15=17 c d+18 a b ; 16=30 a b+19 a b ; 17=19 c d+20 a b ;$ $18=20 c d+21 \mathrm{ab} ; 19=21 \mathrm{~cd}+22 \mathrm{ab} ; 20=22 \mathrm{~cd}+15 \mathrm{ab} ; 21=15 \mathrm{~cd}+13 \mathrm{ab} ; 22=$ $13 c d+23 a b ; 23=23 c d+25 a b ; 24=26$. There ends the text. Deciphered by Usha Colas Chauhan.

F: $\quad$ The text printed in Foucaux 1867.

H: Harvard University 748.4 folia. $11 \times 25.5 \mathrm{~cm} .5$ lines per page. 10 lines with

11 Pathak may have consulted editions of the works of Śankara, but this is not absolutely clear.

12 The New Catalogus Catalogorum (Veezhinathan, Sundaram and Gangadharan 1988: 113115) lists an impressive number of manuscripts of what in most cases is probably our text (but it clearly confuses it with the identically named work of Śuka, and thus one must examine every reference to ascertain which text is in fact at issue, which is not practical, especially since the Catalogus refers to numerous handwritten lists). It proved impossible, moreover, to obtain copies of most of these. However, at the same time, I did obtain copies of several manuscripts not reported in the Catalogus. It would have been ideal at the least to have a geographical representation of manuscripts, but this was also not possible. In particular, a manuscript from Kashmir would be helpful, but it is at the same time unlikely to produce anything surprising. That said, the variance of $D$ indeed suggests that a wider survey might yet yield some surprises. 
interlinear comments in Old Gujarati. ${ }^{13}$ Nāgarī. After the racitā verse (see below) we read: iti śrīpraśnottararatnamālà prakaranaim bālà vibodha samipūrnạh || sādhvīśrïdarșaśrīpatanārgha śubham bhavatu\|. (Generally pc [post correctionem] readings are not accompanied by ac [ante correctionem] readings because these are not legible.)

I: RE33572b in the Manuscript collection of the French Institute of Pondicherry, 5 folia $\left(165^{a}-169^{b}\right)$ on palm leaf, Tigalari script. [http://www .ifpindia.org/digitaldb/online/manuscripts/show.php?no=RE*33572b]. It begins on $166^{\mathrm{r}}$ with the last two akșaras of verse 7 , but the final leaf $\left(17 \mathrm{O}^{\mathrm{r}}\right)$ contains $4 \mathrm{~cd}$ through $7 \mathrm{~b}$. Deciphered by Kristen de Joseph.

K: Kāvyamālā edition, Durgâprasâd and Parab 189o: 121-123.14

L1: British Library 16o. Add. 26,424a (Bendall 19o2: 55). 10 ×4". 19th c. 13 14 lines per page. Nāgarī. ${ }^{15}$

L2: British Library 311. Or. 3347 (Bendall 1902: 128). Foll. $37^{\text {b }}-374^{\text {b }} \cdot 16$ th -17 th c. Jaina nāgarī. 9 lines per leaf.

N: Nepalese National Archives NAK 1-1152 vi. nīti $24=$ NGMPP A 23/14 (ID 54639 (o)), 4 folios, $21.5 \times 4.0 \mathrm{~cm}$. Palm leaf, in Newari script. [http:// catalogue-old.ngmcp.uni-hamburg.de/mediawiki/index.php/A_23-14_ Pra\%C5\%9Bnottaram $\% \mathrm{C}_{4} \% 81$ lik\%C4\%81] This is probably the oldest manuscript source used here. Kindly read by Péter-Dániel Szántó.

P1: Paris Sanscrit 924: [https://archivesetmanuscrits.bnf.fr/ark:/12148/ cc9820oh]. 19th c., European paper, 5 folia, $35 \times 16 \mathrm{~cm}$. With supralinear commentary in Old Gujarati. ${ }^{16}$ What were evidently missing or damaged

13 Here and below my knowledge about the language of the interlinear notes comes through the kindness of Dhaval Patel (email $20 \mathrm{X}$ 2018), to whom my thanks are due. Note, however, that others have suggested the language as Old Hindi. Being entirely ignorant of both, I cannot offer more.

14 The sources of this edition are noted as follows: praśnottararatnamālāyāh pustakadvayam asmābhir āsāditam. tatra prathamam ekapattrātmakaṁ śuddham samivegisādhuśrišáantivijayamunibhir dattam ka-samjñakam. dvitīyam pattradvayātmakaṁ śuddham bhagavāndāsaśreșțhinā kevaladāsātmajena suratanagarāt prahitam kha-samjjñakamj jñeyam. I distinguish these sources as cited in the edition as $k a$ and $k h a$.

15 The text is preceded by namah sambhave and the following verse (meter Vasantatilakā); with the corrections of Harunaga Isaacson, it reads:

astokavistrtam apāstasamastamoham

astāviyac ca nigamais tamasah parastāt |

yad dhvastaduhkhacayam astamitaprapañcam

tad vastu nistulamude 'stu mama praśastam $\|$

16 This seems to be the item listed by Cabaton 1907: $15^{2}$ as item 924, though he says it is 11 folia. The manuscript is dated: iti śrīpraśnottararatnamālā samāptāh $\|$ samvat 1823 varșe miti āgrahāyanasud̄̄ 11 tithau ravivāsare, that is December 22, 1901 (Sunday). 
akșaras in the source of the mūla are represented with lines - . However, the vernacular commentary appears to be unaffected by the missing text. Nāgarī. (This is by far the worst of the manuscripts collated here.)

P2: Paris Sanscrit 16o9 [https://archivesetmanuscrits.bnf.fr/ark:/12148/ cc788ij]. $23.8 \times 10.7 \mathrm{~cm}$. Nāgarī, with interlinear commentary in Old Gujarati. Folio 6 ends with verse 23, folio 7 begins with verse 27; it appears that a folio has been lost. ${ }^{17} 4 \sim 5$ lines of main text per page, depending on the volume of commentary.

Penn: University of Pennsylvania Ms Coll 39o [bibid: 9959998993503681; Penn Ms: http://openn.library.upenn.edu/Data/ooo2/html/mscoll39o_ item570.html]. 4 folia, $13 \times 25 \mathrm{~cm} .7$ lines per leaf. Nāgarī.

S: Works of Śan்karācārya: Anon. 1910: 87-104, almost identical to Bhagavat 1952: $89-94 .{ }^{18}$ This version contains 67 verses. No sources for the text are cited anywhere.

This small sample does not allow us to generalize about the textual tradition of the text as a whole. It is to be noted that the ordering of verses is in several sources slightly different, and in $\mathrm{D}$ radically different; only a survey of a broader range of manuscripts would allow an appreciation of how wide-spread this textual diversity is. In terms of lineages, again, our small sample size makes any conclusion difficult, but it is interesting to note that I and Penn, for instance, although written respectively in Tigalari and Nāgārī, clearly belong to the same tradition.

\section{The Tibetan Translation}

The Tibetan translation of the text to which it gives the Sanskrit title Vimalapraśnottararatnama $l^{19}{ }^{19}$ is found in found in all five available Tanjurs, in some of them twice (as below). It is given a Tibetan title as follow: bod skad du I dri ma med pa'i dris lan rin po che'i phreng ba zhes bya ba. ${ }^{20}$ As is evident

17 This seems to be the manuscript listed by Filliozat 1936: 135, MS 1605: item 180 in his list.

18 These are identical; both contain 67 verses, that is, the "longer" version of the text, which is evidently our recension with the addition of sometimes clearly "Hindu" content. Most popular translations of the text render this longer version, or some abbreviation thereof.

19 The texts read as follows: rgya gar skad du | bi ma la pra shno ta ta ra ratna mā li nā ma $\|$. Three (obviously related) versions have a slightly different reading: G2, N2, P2: bhi ma la pra shod tra ra ratna ma ma le nā ma.

20 With the following variants: dris lan] N2: 'dris lan. P1 reads the whole: dri med dri lan rin chen phreng ba bzhugs so $\|$. When the title appears at the end directly before the colophon, 
from the edition below, there is an extremely close correspondence between the Tibetan translation and the available Sanskrit, ${ }^{21}$ something emphasized in the edition by the editorial choice to select among variant readings of the Sanskrit those that appear to be closest to the Tibetan rendering, all other things being equal. The present edition may in this sense be said to represent an attempt to recover something like the Vorlage of the Tibetan translation.

The Tibetan translation is attributed to a team of two, as mentioned in its colophon:

rgyal po chen po snyan ngag mkhan gyi dam pa slob dpon donyod 'char gyis mdzad pa rdzogs so || || rgya gar gyi mkhan po ka ma la gupta dang | zhu chen gyi lo tsā ba dge slong rin chen bzang pos bsgyur cing zhus te gtan la phab pa'o $\|^{22}$

Composed by the Mahāāāja Paramakavi Ācārya *Amoghavarșa. Translated by the Indian Ācārya Kamalagupta and the Great Translator Rin chen bzang po, it has been revised and finalized. ${ }^{23}$

Some attention must naturally be given here to the translators (the author will be discussed below). The team of Kamalagupta and Rin chen bzang po (958-1055) is credited with a number of translations, in addition to our text

there are no variants, however: drima med pa'i dris lan rin po che'i phreng ba zhes bya ba $\|$.

21 Notice the comment of Martin 2008: 16 a propos Rin chen bzang po: "The Tibetan translations he made are often admired for their close adherence to the Indian texts, but they reproduce the original grammar and syntax to a degree that makes their comprehension very difficult — difficult that is without resorting to oral explanations and/or written commentaries-for Tibetans who might be unable to read through the Tibetan words to the words of the Indian original."

22 Variants:

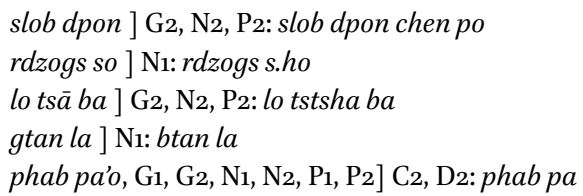

23 This translation basically follows Cordier 1915: 344 (mdo-hgrel XXXIII.35) and 483 (mdoh.grel CXXIII.31). Cordiner offers Amoghodaya (as had Schiefner 1858: 22), with the notation that reading char in place of 'char suggests Amoghavarșa. The latter is certainly better in light of Sanskrit sources. Kanakura 1935: 418-419, in my view absurdly, rejects this, which leads him to refuse to recognize the Jaina origins of the text translated into Tibetan. The name Amoghodaya, in my view, although sometimes cited, should be considered a ghost. See below. 
these being: Mahāparinirvānasūūtra (Derge [Tōhoku numbering] 121 [below D]); Mañjuśrīnāmasañgīti (D 360); Nairātmyāpariprcchā (D 173); Catuhpiụthayogatantrasādhana (D 1610); Tattvopadeśa (D 1632); Tattvopadeśavrtti (D 1632). They are also credited with the Arapacanasādhana (D 3311), but perhaps problematically. The same team, with the addition of Śraddhākaravarman, is credited with translations of the *Paramādyațīkā (D 2512); Mañjuśrīnāmasañgititțika (D 2534); and Pañcakrama (D 1802). ${ }^{24}$ Kamalagupta evidently hailed from Kashmir, and it is possible that this region supplied the base text upon which the Tibetan translation was based, but see below for a discussion of several indicative errors in the Tibetan translation which suggest an Eastern Indic script for the Vorlage. ${ }^{25}$ As a closing verse demonstrates (see below), the source manuscript used by the translators evidently came from a Jaina milieu. For his part, Rin chen bzang po is of course one of the most renowned translators in Tibetan history. ${ }^{26}$ When one looks at the list of works Kamalagupta and Rin chen bzang po translated together, however, comprised almost entirely of tantric texts, it is not obvious why they should have chosen to translate the Praśnottararatnamālikā, and the reason and circumstances must, for the present, remain unknown.

Be that as it may, since the translators worked in the far west of the Tibetan Himalaya, it is slightly surprising that a small fragment has been recovered from the site of Khara-khoto, a Tangut town in what is now western Inner Mongolia. The fragment is preserved in the British Library under the shelf number IOL Tib M $135 .{ }^{27}$ Evidently it had been placed in a stūpa located near the northwestern corner of the town. ${ }^{28}$ It might not be unreasonable, on palaeographic

24 Without Rin chen bzang po, Kamalagupta together with Lha Ye shes rgyal mtshan is credited with renditions of the Vajrahrdayālañkāratantra (D 451), Dvikramatattvabhāvanā (D 1853), and Ratnavrkșa-nāma-rahasyasamājavrttti (D 1846). With Bsod nams rgyal ba, he is said to have translated the Las dang po pa'i dam tshig mdor bsdus pa (D 3726).

25 See Sørensen 1994: 455-456n1673. I owe this reference and the list of translations to Dan Martin's invaluable TibSkrit.

26 See conveniently https://treasuryoflives.org/biographies/view/Rinchen-Zangpo/TBRC_ P753. Gangnegi 1998 is also of interest, and of course Martin 2008.

27 Identified and edited in Takeuchi and Iuchi 2016:71 as catalogue entry 107. I owe my thanks to Sam van Schaik for providing me with high resolution color photos which enabled me to reread the leaves, but it must be noted that it was primarily my possession of a collated edition of the text which allowed me improve even very slightly indeed the fine decipherment of Takeuchi and Iuchi.

Given the near identity of the date of translation and the closing of the manuscript cave at Dunhuang, it is entirely expected that no evidence is to be found there.

28 Takeuchi and Iuchi 2016: 7. "The majority (253 out of 285) of the Tibetan manuscripts from Khara-khoto were taken from [this] site." 
grounds, to date the manuscript to between the $13^{\text {th }}$ and $15^{\text {th }}$ centuries. ${ }^{29}$ This also contains some interlinear notes, though only to a few phrases. As the fragment's reconstruction indicates that this leaf contained almost exactly the first half of the text, we would expect there to have been one additional leaf. As the spacing between the lines of verse is irregular, it is difficult to know exactly how big the leaf would have been. However, the catalogue cites the dimensions of the fragment as $10.5 \times 20.0 \mathrm{~cm}$. The photos provided to me have a scale, which allows more precision: the vertical dimension is indeed almost precisely $10 \mathrm{~cm}$, and the length of the longest preserved line is approximately $17 \mathrm{~cm}$. This allows us to calculate an original size to the leaf of approximately $10 \times 60 \mathrm{~cm} .{ }^{30}$ In order for the surviving portions to line up, the text most probably would have included both a Sanskrit and Tibetan title, after which the end of the Tibetan title and the invocation survive.

It is noteworthy that a portion of two lines which appear to have dropped out of the Tanjur textual transmission has survived, in the midst of what is numbered here as Tibetan verse 19. What we have in the Tanjurs as the 19th verse reads as follows:
shin tu bde ba gang zhe na $\|$
'du 'dzi kun la ma chags pa'o $\|$
srog chags rnams kyi dga' bya gang $\|$
don yod 'tsho ba'i srog nyid do $\|$ [19]

To the first two lines corresponds Sanskrit kim saukhyam sarvasangaviratir yā, foot $b$ of the Sanskrit verse 12. Similarly, the final two lines correspond to foot d, priyam ca kim prāninām asavah. What evidently originally formed part of the Tibetan translation, however, is only partially preserved in our fragment, as follows (on the verso, line 4): /// zhe na \| yang dag phan par 'gyur ba'o \|, which plainly represents the Tibetan rendering of foot c, kim satyam bhütahitam, or perhaps the reading of other manuscripts, kim sādhyam bhütahitam. Since the question portion is precisely what is missing, we cannot say which of these two readings of the question lay behind the Tibetan translation. The preservation of this verse, albeit partially, in Tibetan is particularly significant in illustrating that, evidently at some point after the production of the manuscript preserved

29 Taking a clue from the indications in Takeuchi and Iuchi 2016: 9, 11-13.

30 Looking at fully preserved folia, the manuscript numbered 208 in Takeuchi and Iuchi 2016 has the dimensions $10.2 \times 66.1 \mathrm{~cm}$; 209 is $12.5 \times 61.0$; 267 is $7.6 \times 61.1$; and 277 is $5.5 \times 61.6$. Therefore, the reconstructed dimensions are plausible at this site. 
in Khara-khoto, two lines of the text otherwise preserved in the Tanjur somehow disappeared from the textus receptus.

The transliteration below illustrates the context of the surviving portions by quoting whole verse lines; the extant material is printed in roman type, that provided for context is given in italics. As above, a reconstruction taking account of the placement of surviving words allows us to be fairly certain that the text began at the left margin of line 1 of the recto with the title in Sanskrit: rgya gar skad du | bi ma la pra shno ta ta ra ratna mã li nā ma $\|$. Following this the latter portion of the Tibetan title and the invocation survive: bod skad du | dri ma med pa'i dris lan rin po ce' ï 'phreng ba | | 'jam dpal gzhon nur gyur pa la phyag 'tshal lo $\|$. This invocation offering honor to Mañjuśrī kumārabhūta shows that, centuries before the compilation of the Tanjur, at least its translators, or the scribe(s) who copied it, were themselves Buddhist, although, as Prof. Isaacson reminds me, this does not necessarily imply that they considered the text they were transmitting to itself also be Buddhist. ${ }^{31}$

The remainder is given line by line, beginning with the recto:

2: bcom ldan blang bya gang zhe na || bla ma'i don ldan tshig rnams so || spang par bya ba gang zhe na $\mid[2 \mathrm{a}-\mathrm{c}]$

3: 'khor ba'i rgyun ni [space] ye gcad pa'o || thar pa'i zhing mchog [sa]

bon gang | [4bc]

4: bye brag ji zhin phyed pa'o || gdug pa'i dug ni gang zhe na || bla [ma]

brnyas $[b] \mathrm{ye}[d]$ gang yin pa'o $\|[6 \mathrm{~b}-\mathrm{d}]$

5: mi srun dgra 'dra gang zhe na || myi bzad pa'i yul rnams so || 'khor pa'i

'khri shing gang zhe na $\|[8 \mathrm{~d}-9 \mathrm{a}]$

6: phung khrol' $\mathrm{d}[o] \mathrm{d}$ chags can rnams so $\|$ skyes $\mathrm{b}\left[u d p a^{\prime}\right]$ bo gang zhe [na $\|$ [1od-11a]

Verso:

1: || tshang tshing myi bzad gang zhe na || bud my[e]d rna[ms kyi spyod pa'o $\|[13 \mathrm{ab}]$

2: don yod tsho ba gang zhe na || kha na ma tho myed pa'o \| [skyes bu] glen pa gang zhe na $\|[15 \mathrm{a}-\mathrm{c}]$

3: mi brtan myur 'jig gang zhe na || skyes bu rnams kyi lang tsho dang || no[ $r$ dang $]$ de $[b]$ zhin tshe nyid do $\|[17 \mathrm{~b}-\mathrm{d}]$

31 As one example, in the Tibetan translation of Kālidāsa's Meghadūta (Beckh 19०7: 5·3), never to be confused with a Buddhist work, following the title we nevertheless find: yang dag par rdzogs pa'i sangs rgyas gsung gi dbang phyug la phyag 'tshal lo. 
4: [5 words lost] zhe na || yang dag phan par 'gyur ba'o || srog chags rnams la dga['bya gang $\|$ [19; see above]

5: gang zhig tshul khrims phun 'tshogs pa'o || tshig gi [ $r$ ]gyan 'gyur gang zhe na $\mid[21 b c]$

6: phongs pa kun 'jig $m$ ] khas pa gang || thams cad du ni skal ldan pa'o | [| skyes bu d]mus [long] ga [ng zhe na $\|[23 \mathrm{a}-\mathrm{c}]$

It is very interesting that there are several interlinear glosses in this manuscript. ${ }^{32}$ Although (see above) some Sanskrit manuscripts contain often copious interlinear commentary, the sparse glosses here seem to be of Tibetan origin, rather than reflecting some pre-existing Sanskrit glosses, although there is no way to be certain about this. That below the first foot on recto 4 is unfortunately virtually illegible, but under the 'dod chags of recto 6 we read 'khrig, sex, intercourse. ${ }^{33}$ On recto 5 beneath myi bzad pa'i yul rnams so [8d], "The horrid [sense] realms," we read: dbang po'i yul lam gnas, and then slightly displaced: yul drug gam sdig 'phel ba'o. This might be something like: "The object sphere or condition of the senses," followed by: "six spheres of the sense objects, or increasing sin." ${ }^{34}$ On the verso, it is particularly valuable that the foot otherwise not preserved in the Tanjurs, yang dag phan par 'gyur ba'o, is glossed: above the line over dag phan we find rang gzhan la, and beneath it we read phyi ma la, that is, respectively, "to self and others," and "in the future." In all, the expression then should be understood as something like, "What will offer benefit to self and others in the future."

Finally, beneath thams cad du ni skal ldan pa'o on verso 6, we find bsod nams, normally an equivalent of punya. The Sanskrit line (14cd) here is sarvaryasanavināsé ko dakșah sarvathā tyāgi, "Who is adept at destroying all addictions? One who is in every respect a renunciant." The Tibetan translation (23ab) reads: phongs pa kun 'jig mkhas pa gang $\|$ thams cad du niskal ldan pa'o $\|$. This was perhaps difficult to understand, ${ }^{35}$ although it has not been remarked that it differs palpably from the Sanskrit. A reason for this difficulty may be that it represents a mistranslation: skal ldan pa'o evidently represents a misreading of tyāgi as *bhägi. This would be very easy to explain if the Vorlage were written in the Sāradā script, and it is not hard to imagine that a text translated in West-

$32 \quad$ I was greatly assisted by Berthe Jansen in deciphering and interpreting these.

33 My thanks to Dan Martin for his help here.

34 Once again I am profoundly indebted to Dan Martin for his help here.

35 Schiefner 1858: 25 offered, without comment: "Wer ist der Weise, der Armuth vernichtet? Der gegen alle Gabenreiche." Others, as far as I see, do not comment at all, including Kanakura 1935 [1944]: 436 . 
ern Tibet would have a Kashmiri origin. In Śāradā, tyā and $b h \bar{a})$ are very similar. ${ }^{36}$ While it is true that there exists no form *bhyāgin, this confusion seems an obvious explanation. If one would understand thams cad du ni skal ldan pa'o as "one who in every respect possesses virtue," the gloss seems to take this, then, as religious virtue, punya.

Despite this explanation based on the Śāradā script, another error in the Tibetan translation points in a different direction. ${ }^{37}$ Sanskrit $26 \mathrm{c}$ reads ty $\bar{a}$ gasahitam ca vittam, but its Tibetan equivalent ( $40 \mathrm{Ob}$ ) is sems ni rnal 'byor ldan pa'o. Now, the (rather obvious) confusion of vitta for citta was already noticed by Foucaux 1867: 8on1. However, the explanation for tyāgasahitam = rnal 'byor Idan pa is not possible in Śāradā, nor altogether obvious. If, however, the Vorlage were written in a script which employed the prșțhamātrāa, then it is far from difficult to confuse tya with yo. ${ }^{38}$ We find from an eleventh century manuscript, for instance, tya written हा, and $y o$ as त्या. Moreover, regarding the above mentioned confusion of tyāg $\bar{\imath}$ as ${ }^{*} b h \bar{a} g \bar{\imath}, b h \bar{a}$ is written in this script as $\boldsymbol{\Re}$, and bhya as \$ू. Note moreover that in what Gustav Roth and Édith Nolot (table in Nolot 1997) agree in calling "Proto-Bengali-cum-Proto-Maithili," the script of the manuscripts of the Mahāsāmghika-Lokottaravādin Bhikșuṇi Vinaya and Abhisamācārikā Dharmāh, tyā and bhyā are again virtually indistinguishable. It therefore seems rather likely that these errors, evidently based not on a source text different from the Sanskrit now available to us but instead on a misreading of the manuscript, point to some Eastern Indian origin for that manuscript.

The so-called canonical sources for the Tibetan edition are as follows:

G1: Golden Tanjur 3411 dbu ma, gi 103b5-106a.

N1: Narthang Tanjur gi 82a6-84a2.

P1: Peking Tanjur 5412 dbu ma, gi, 93b1-95a5.

C2: Cone Tanjur 4297 thun mong ba lugs kyi bstan bcos, ngo, 121a3-123b3.

36 The reference characters are taken from the table "Akṣara List of the Manuscript of the Abhidharmadipa (ca. the 11th Century, Collection of Sanskrit Mss. Formerly Preserved in the China Ethnic Library)," (c) 2009, Research Institute of Sanskrit Manuscripts \& Buddhist Literature, Peking University, prepared by Saerji 萨尔吉. A Śāradā manuscript of the Praśnottararatnamālikā is in fact referred to in Aufrecht's 1892 catalogue of the library in Florence, page 152, item 430 (14), on folio 261 b.

37 I owe this insight to Peter Szántó.

38 The following example is drawn from: "Akșara List of the Manuscript of the Saddharmapuṇuarīkasūtra, (1082 CE, Collection of Sanskrit Mss. Formerly Preserved in the China Ethnic Library)," (c) 2005 Research Institute of Sanskrit Manuscripts\&Buddhist Literature, Peking University, prepared by Ye Shaoyong 叶少勇. 
D2: Derge Tanjur 4333 sgo rig pa, ngo 126b6-127b6. ${ }^{39}$

G2: Golden Tanjur 3828, lugs kyi bstan bcos go 259 b5-261b5.

N2: Narthang Tanjur go 191a2-192b3.

P2: Peking Tanjur5825, thun mong ba lugs kyi bstan bcos, go, 172b3-174a5.

In the edited text below, the Khara-khoto manuscript fragment is quoted as $\mathbf{K}$ k.

Major variants are given with the text, less significant readings are found in Appendix 3.

As noted above, Pavolini 1898 published a Prakrit version of our text. Velankar 1944: 276 refers to a Praśnottararatnamālā by Bhavyottama Muni, which he says is a Prakrit rendering of our text; I do not know if this is meant to be the same. Velankar cites Jaina Hitaiși, A Hindi monthly magazine, vol. 13, pp. 109 ff., which I have not been able to locate. As again noted above, Melinda Fodor will shortly published a revised edition of this version.

\section{$5 \quad$ Title}

The text bears a number of titles, more or less closely related to each other, including: Praśnottararatnamālikā, Praśnottararatnamālā, and Praśnottara$m \bar{a} l \bar{a}$. The title found in the Tibetan tradition, Vimalapraśnottararatnamāli, seems likely to have been motivated by a misunderstanding of the final verse (27ab): iti kaṇthagatā vimalā praśnottararatnamālikā yeșām, in which the key terms are rendered in Tibetan dri med dris lan rin chen phreng ba, a nearly exact metrical representation of the title given in the Tanjurs, dri ma med pa'i dris lan rin po che'i phreng ba. This version of the title, therefore, should be considered an error from the Indic perspective.

39 I have reference to another copy in the same edition, but could not obtain a copy: D1: 4499, jo bo'i chos chung, gi 75b4-77a5. I do not know where the other copy would also be in the Cone edition, but given the availability of so many witnesses, it does not seem a crucial omission. 
The question of the authorship of the Praśnottararatnamālikā has been discussed in the scholarship with, it seems to me, sometimes a curious credulity. Let us first look to the attributions found in our sources.

Some manuscripts appear to attribute the text to an author named Vimala: ${ }^{40}$

racitā sitapațaguruṇā vimalā vimaleti ratnamāleva| praśnottaramāleyaṁ kaṇthagatā kimin na bhūșayati\|

Haridas Sastri (189o, 378, reading vimalena for vimaleti) rendered as follows: "This excellent series of questions and answers, composed by Vimala, a teacher clad in white garments, - does it not adorn one who can recite them, just as a garland of pure gems enhances the beauty of a man when placed on his neck?"41 I will return in a moment to the question of who this Vimala might have been. However, this is not the only option for authorship.

The inclusion of the text in the works of Śankara asserts an attribution to Śankara. And indeed, F and I (with only slight variations in Penn) end with:

\section{racitā śaṁkaraguruṇā vimalā vimalena ratnamāleyaì $\|$ praśnottararatnamayī kaṇțagatā kaṁ na bhūṣayati \|}

This is followed in F and Penn by: iti śrišamikarācāryaviracitā praśnottararatnamālikā samāptāh ||. In D we find: iti śrimmacchamikarācāryaviracitapraśnottararatnamālikā samāptā, and in C iti śamkarācāryaviracitā praśnottararatnamālikā sampūrnaim || śivārpanam astu ||. It is plain that these manuscripts, in both the verse (in F and Penn) and the colophons, attribute the authorship of the text to Śankara. ${ }^{42}$

40 In our sources, the verse is in $\mathrm{H}, \mathrm{K}, \mathrm{P} 1, \mathrm{P}_{2}$. Variants:

vimalā ] $\mathrm{K}(k a)$ : vimalena

vimaleti ratnamāleva ] P2: vimaleva ratnamāleṇa; H \& Sastri 189o, 378: vimalena ratnamāleva

praśnottaramāleyam ] P2: praśnottaramāleṇa; H: praśnottara/margin: ratna〉māleyam bhūṣayati ] H: bhūṣayaminti

41 This, incidentally, brings out what is at least the same play on words, if it is not an actual śleșa, that appears in the first true verse of the text with the same, or almost the same, word, here kanthagata, in verse 1 kant thasthita.

42 In the anonymous 1910 edition of the works of Śankara, the text is followed by: iti śrimatparamahamisaparivrājakācāryasya śrīgovindabhagavatpūjyapādaśisyasya śrīmacchañkarabhagavatạ̣ krtau praśnottararatnamālikā sampūrṇā. 
While there seems to be no reason to associate the authorship of the text with the famous 8 th c. Sankara, ${ }^{43}$ the similarity of wording in the two verses cited above also casts doubt on Sastri's understanding of Vimala as a name. Perhaps in an attempt to overcome this issue, Pathak (1958a: $93=1974: 29)$ understands the juxtaposition with Śamkaragurunā to mean that Vimala was "teacher of Śankara" (he uses no article, a or the, so it is hard to know exactly what he means), but no such figure seems to be known; Śankara's master was, famously, Govindapāda (or Govindabhagavatpūjyapāda).

This is not the only attribution, however. Sastri cites other manuscripts which have instead the reading cited in $\mathrm{K}(k h a)$ :

\section{vivekāt tyaktarājyena rājñeyami ratnamālikā | racitāmoghavarșeṇa sudhiyām sadalamikrtih \|}

This appears to be more or less precisely the source of the last verse of the Tibetan translation:
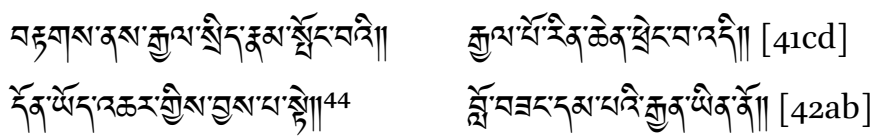

Sastri renders the Sanskrit: "This garland of gems, an excellent ornament for the learned, was composed by king Amoghavarsha, who gave up his kingdom owing to his discriminative knowledge." Note that the Tibetan here, being evidently based on a manuscript with this form of the verse, therefore almost certainly renders a text belonging to the Jaina tradition. It did not take long for this attribution to "Amoghavarșa" to be given historical credence, but this tendency began even earlier. Seven years before Sastri's publication, Fleet 1883: 218 had cited the verse after "Mr. K.B. Pathak [who] has also brought to my notice a short poem named Praśnôttararatnamâlâ on the rules of good behaviour," and following his citation and translation of the verse, ${ }^{45}$ he added: "The Amôghavarsha mentioned here, however, may be either the first or the second or the third of that name."

43 In a message to the Indology list on 29 August, 2018, David Reigle wrote: "each of the mațhas started by Śankarācārya has a long line of adhipatis up to the present. Each adhipati also has the title Śan̉karācārya. So there have been many Śaṅkarācāryas after Ādi Śankarācārya. The idea, then, is that the majority of the more than 400 works attributed to Śan̉karācārya are actually by later Śan̉karācāryas, not by Ādi Śańkarācārya, even though they are usually taken to be by Ādi Śan்karācārya."

44 It is evident here, as discussed above, that we must read rather char, not 'char.

45 In which, reading sudhiya, he rendered "learned king," also a possibility. 
Perhaps having forgotten his own earlier contribution, to which he does not refer, however, not long after Sastri's 189o paper appeared, Fleet 1891 published "A note on Amoghavarsha I," in which he combines this verse with a fragmentary inscription he discovered at Aihole, and which "probably proves that the king whose name is connected with the book in question, is the Râshțrakûța king Amôghavarsha I." He further wonders, based on the small fragment of the inscription which he could read, whether the king could have abdicated (apparently due both to the expression vivekāt tyaktaräjyena and to the presence in the inscription of the word navaräjyam), and then adds: "Or is it possible that the verse in the Praśnottara-ratnamālikā is euphemistic; and that, in reality, he was overthrown for a time by the Eastern Chalukya king Vijayâditya II ...?" I think that in this respect, sadly, Fleet is not a faithful guide, and his credulity seems to have led to this (rather wild) speculation becoming established historical fact for Duff 1899: 79, who in a chronological sketch under the year 877 writes that "according to a Kanheri inscription, Amoghavarsha was still king in Ś[aka] 799. A possible explanation of this lies in the statement of the Praśnottara-ratnamālikā that Amoghavarsha abdicated the throne to lead a religious life." ${ }^{36}$ Now, as Fleet noted, there are indeed at least four historical Rāșțrakūța kings named Amoghavarșa, the first of whom is dated to Śaka $736 / 8-799$, that is, $814 / 6-877 \mathrm{CE}$. There is, however, not the slightest historical evidence to support any connection of any of these figures with the Praśnottararatnamālikāa ${ }^{47}$

46 This is not the only example of this type of logic. Barnett 1928: 1239 says of the author he calls Vimala-Chandra Sūri that he is the author of a "Praṣnottara-ratna-mālā. A Jaina catechism in 30 verses, by Vimala[-chandra], the latter being a name traditionally believed to have been assumed by the Rāshțrakūṭa king Amogha-varsha on entering the religious life."

47 K.B. Pathak himself (1902, a paper delivered in 1898) had already implicitly indicated some of the problems encountered by such reasoning. By reminding readers that "A few years ago I discovered a small Jaina work entitled Praśnôttararatnamâlâ," and citing Fleet 1883, he indicates his ignorance of the earlier European publications of the text. Aware, however, of Schiefner's work (apparently only secondarily through Bhandarkar 1895: 68$\left.69^{*}\right)$, after quoting the same verse, and noting that several editions of the text have been published in Bombay (no references are given), he goes on: "It is variously attributed to Śan̉karâchârya, Śankarânanda, and a Śvêtâmbara writer named Vimala. But the royal authorship of the Ratnamâlâ is confirmed by a Thibetan translation of it discovered by Schiefner, in which the author is represented to have been a king and his Thibetan name, as re-translated into Sanskrit by the same scholar, is Amôghavarsha. This work was composed between Śaka 797-799; in the former year Nripatunga abdicated in favour of his son Akâlavarsha."

* It is curious that although Bhandarkar 1895: 69n2 refers to Weber's edition, this name is not even mentioned by Pathak. Perhaps he had no access to it? 
If we discard the attribution to Śankkara, which likewise virtually all modern scholars seem to have happily done, and we set aside Amoghavarșa, or at least the connection of this name with the famous king (or any kings of that line, for that matter), what of Vimala? Peterson (1883: 50, 58-59 of Appendix I), quotes manuscripts that begin pranipatya jinavarendram, illustrating their Jaina affiliation. These manuscripts end with a verse, almost the same as that cited above, save for one crucial difference: ${ }^{48}$

\section{racitā sitapațaguruṇā vimalā vimalena ratnamāleva praśnottaramāleyam kam̦ṭagatā kaṁ na bhūṣayati}

Peterson 1887: 44 would identify this Vimala (whom he takes as the author) with Vimalasūri, the author of the Prakrit work Paümacariya (Sanskrit Padmacarita). He writes "The Padmacharitra of Vimalasūri ... will I believe turn out to be an important find, if, as seems to me probable, the Vimala of this poem is the author of the Praśnottararatnamālā." He goes on, after noting that the Cambay Palm-leaf library contains 10 copies of the latter work, to refer to his own work on the Hitopadeśa, a text which contains (as I.156) one verse also found as Praśnottararatnamālikā 25, saying:

It does not seem to me to be doubtful that the verse in the Hitopadeśa priyavāksahitam dānam is in that book a quotation from Vimala's Praśnottararatnamālā, where it stands in its own context, so to say, as one of a series of answers to a series of questions. I had at first hoped to find a useful datum for the age of the Hitopadeśa in a circumstance which has of course already attracted attention [here he refers to Weber's Indische Streifen, p. 210]. But it does not seem possible at present to fix Vimala's date, or even to say with certainty to what religious sect he belonged, and in all probability he is earlier than references we already have for the Hitopadeśa. The Vimala who wrote this book was a pupil of Vijaya, who was pupil of Rāhu. Vijaya's name as that of an old teacher occurs in the praśasti of the Rayamallābhyudayakāvya [ref. omitted_JAs] .... If this Padmacaritra or Rāmacharitra is really the work of the Buddhist author of the Praśnottararatnamālā, its importance for the history of the Indian epics can hardly be exaggerated.

48 This is not the only source; the same verse is found in our manuscript $\mathrm{H}$. In foot c, ${ }^{\circ} \mathrm{ratna}^{\circ}$ is added in the margin before ${ }^{\circ}$ mäleyam, and kam is 'corrected' to kim. The text printed in K ends: iti śrivimalaviracitā praśnottararatnamālā. The vrtti of Devendra (see below) also attributes the text to Vimalacandrasūri. 
It is to be noted here that Peterson considered the Praśnottararatnamālikā to be a Buddhist text. Sastri 189 o responded to Peterson, writing, "Now, having examined a number of copies of the Praśnottara-Ratnamâlâ, I am in a position to disprove that the author of it was even a Buddhist, or that he had any connection with the Padma-purâna or Padma-Charita referred to, the author of which distinctly gives his date in the closing stanzas of his ... poem." He goes on, after some considerations of kings named Amoghavarșa, to aver that the author of the Praśnottararatnamāla must have been a Jaina, understanding the expression sitapațaguru to mean "'a teacher clad in white garments,' that is, a Jaina Sâdhu of the Śvetâmbara sect. If, on the contrary, Amôghavarsha was really the author of it, the poem must be regarded as a Digambara work." V.M. Kulkarni in Jacobi and Punyavijayaji 1962-1968: 8-25 surveys what can be known of the date, life and sectarian affiliation of Vimalasūri, author of the Paümacariya. Yet, however thorough this study, I believe it is not relevant here, since there is no evidence at all that this author is to be connected with our text, other than the (apparent) coincidence of names. Among other reasons, Vimalasūri's poem the Paümacariya is in Prakrit, not the Sanskrit of our text, and our text moreover contains not a single Jaina idea. Peterson's suggestion that the Hitopadeśa tradition borrowed a verse does not seem in itself necessarily problematic, but since the textual tradition of that work is so fluid, this is not necessarily very helpful, and it would be equally likely that our text has borrowed a verse either from the Hitopadeśa, or which found its way into that text as well. It is, apparently, only the assumption of a considerable antiquity for the author—as Peterson sees it—of the Praśnottararatnamālikā that assures him that it must pre-date the compilation of the Hitopadeśa. But since I believe that in fact all efforts to identify an author for the Praśnottararatnamālikā so far have been in vain, ${ }^{49}$ this assumption of relative chronology seems to me groundless. Rather than drawing conclusions based on such assumptions, I think that what emerges from the considerations above is that every scholar to offer an opinion has evidently been reaching for some certainty in a situation without any firm evidence. Some, indeed, seem to have been primarily motivated to claim the authorship of the Praśnottararatnamālikā for their own sect (see also below), and this cannot help but slant their analyses. We cannot, I think in conclusion, know who the author of the text was, nor perhaps even his sectarian affiliation, or date. The very earliest attestation we have comes from

49 Gāndhī 1949 also comes to the conclusion that the author was Vimalasūri. I extend my great thanks to my colleague Abhishek Avtans for reading and summarizing this Hindi article for me. 
the Tibetan translation of the first half of the 11th century, but this is no more than a terminus ante quem. What is more, the textual fluidity evident even in the small numer of manuscripts I could examine suggests that the transmission of the text introduced diversities, and at present it is not possible even to attempt to recover its "original" form. We know slightly more about its subsequent history, since the various lineages of the text do not seem to be in the least motivated by sectarian concerns (at least in so far as we are dealing with the core verses, not those I consider supplemental), and this suggests, though it cannot prove, that in the form(s) in which it was taken over into traditions other than that in which it might have originated, it was not seen as strongly sectarian from the outset.

\section{Commentaries}

In addition to the vernacular interlinear commentaries, mentioned above in the manuscript descriptions, catalogues list a number of commentaries on the text. Pavolini 1898: 155 refers to a țika by Rọsuttama (catalogued in Pavolini 1907: 145 , item 762 , where it is however not clearly called a commentary). ${ }^{50} \mathrm{~A}$ vrtti, dating to 1373 , is credited to Devendra (Schubring 1944: 447 , item 893).51 It is cited in some detail in Weber 1891: 1118-1123 (item $§ 2021$ ), ${ }^{52}$ and edited by Vimalabodhi Vijayaju 2005. ${ }^{53}$ According to Weber, Devendra's lengthy text associates every question with a story $(k a t h \bar{a})$, some of which are in Prakrit. In his treatment of the text, he cites the introductory lemma of each verse, and gives the name of the story associated with it. In addition, Velankar 1944: 276 refers to $v r t t i s$ by Hemaprabha, ${ }^{54}$ Munibhadra, Śubhavijayagani, and an anony-

50 Pavolini writes: "Manca il primo foglio. Con un commento bh[āṣa] molto diffuso e con numerose citazioni di strofe s.e. di titoli di novelle." Not in Flügel \& Krümpelmann 2016 under the author's name, but mentioned sv Praśnottararatnamālā, p. 612b. This and the other commentaries noted here are also cited, with references to manuscript catalogues (mostly inaccessible, including many handwritten lists), in Velankar 1944: 276 and Veezhinathan, Sundaram and Gangadharan 1988: 114.

$51 \quad$ Flügel \& Krümpelmann 2016: 494b-495a.

$5^{2}$ Among other manuscripts of this text, one is found in St. Petersberg, and according to its catalogue (Mironov 1918: 154, MS 201), it is superior to that catalogued by Weber. Three verses are quoted to illustrate this.

53 My sincere thanks to Madhav Deshpande for bringing this edition to my notice, and sending me its electronic copy.

54 This is catalogued by Dalāl 1923: 10 as item 9o, who quotes the beginning and end, but the portion he edits does not at first glance appear to refer directly to our text. Two authors with the name Hemaprabhasūri appear in Flügel \& Krümpelmann 2016: 954a; the refer- 
mous work. At least the third of these may not be a commentary on our text at all. All of these appear to be Jaina works.

\section{$8 \quad$ Sectarian Orientation}

The existence of commentaries on the text belonging, apparently exclusively, to the Jaina tradition(s) suggests that the Jainas at the very least adopted the text and devoted to it a certain amount of attention. However, not all sources are exclusively Jaina by any means. And in fact, here the evidence is quite clear that there is no clarity about the sectarian home of the work.

Although it is true that manuscripts may be copied by scribes not necessarily allied with the sect of the patron, this is less interesting for us at the moment than the evidence that at least in the form in which we have them there is evidence for multiple belongings of the various written sources of the Praśnottararatnamālikā. The incipit in manuscript D, for instance, reads śrīkeśavāya namah, that is, with homage to Viṣnu or Krș̣na, while that contained in $\mathrm{C}$ and the Penn manuscript reads: śríganeśāya namah. In contrast to these "Hindu" invocations, according to Foucaux 1867: 70n1, his Calcutta manuscript had here Pārśvanātha, the 23rd Jaina Tīrthankkara.

This variety appears in other ways as well. A mangala verse reads in one version (metre upagiti):

\section{pranipatya mahādevam praśnottarapaddhatim vakșye | nāganarāmaravandyam sarvajñam mokșadaì śāntam ||}

Bowing to the Great God, praiseworthy for nāgas, men and gods, omniscient, who offers liberation and is peaceful, I shall proclaim this guidebook of questions and answers.

For praśnottarapaddhatim in foot $\mathrm{b}(\mathrm{F}, \mathrm{K}[k h a] \mathrm{L} 1),{ }^{55}$ Penn and $\mathrm{P}_{2}$ have the àryā reading praśnottararatnamālikām; P1 keeps the metre but reads praśnottaramālikām. The latter two readings give instead of "guide-book" rather "small [precious] garland." More significantly, in place of mahādevam, H, K (ka), L2, $\mathrm{P}_{1}, \mathrm{P}_{2}$, and F's Calcutta Ms, have jinavaremdram. That is, these manuscripts instead of the reference to the Hindu Śiva, who is Mahādeva, dedicate the text

ence is evidently to the first, pupil of Devendrasūri, but if Flügel \& Krümpelmann 2016: 496 are correct, this figure is distinct from the Devendra mentioned above. 
to the Jina, indicating a Jaina rather than Śaivite orientation (we saw this above with manuscripts catalogued by Peterson as well). In place of sarvajñam mokșadam śāntam $\mathrm{H}, \mathrm{K}, \mathrm{L} 2, \mathrm{P}_{1}, \mathrm{P}_{2}$ have the metrically identical: devaim devādhipam viram. ${ }^{56}$

Of the manuscripts I examined, only $\mathrm{N}$ has a Buddhist incipit, namely namo vāgiśvarāya, an invocation of the Buddhist Mañjuśrī. It is with its Tibetan translation that the text exerts some claim to Buddhist identity. The Tibetan translation follows the title with the invocation 'jam dpal gzhon nur gyur pa la phyag 'tshal lo $\|,{ }^{57}$ that is, homage to Mañjuśri-kumārabhūta, a bodhisattva. In addition to its placement in the Tanjur, this appears to be the only Buddhist indication of the text. For Kanakura 1935: 413, the inclusion of the text twice in the Tanjur is a strong reason to believe in its Buddhist origins, a logic I do not well understand. Not only does the Tanjur contain a variety of non-Buddhist works (Seyfort Ruegg 1995: 108-132, surveying the sciences, medicine, linguistics, dramaturgy, lexicography etc.; Kanakura himself refers to the Meghadūta of Kalidāsa [D 4302]), ${ }^{58}$ special attention seems to have been given to a group of nitti texts, a category to which our work broadly belongs, some of which are clearly non-Buddhist (brief survey in Hahn 1985). These include the Âryākoșa of Ravigupta (D 4331; Hahn 2007, 2008), the Gāthāśataka of Vararuci (D 4332; Hahn 2012), the Cānakyarājanitisisāstra (D 4334; Pathak 1958b; Sternbach 1961), and the Nîtiśāstra of Masūrākṣa (D 4335; Pathak 1961; Sternbach 1962). According to Sternbach (1961: 106; 1962: 411), the Tibetan translators of the Cạnakyarājanitiśāstra, Prabhākaraśrīmitra and Rin chen bzang po, adapted that work Buddhistically, something which we certainly do not see here, despite the (putative) involvement of Rin chen bzang po in both projects. It can be seen that mere inclusion in the Tanjur, then, does not in and of itself provide evidence for the "Buddhist identity" of a work.

As an example of some of the ways the matter has been argued, then, we can trace how Kanakura, having rejected the possibility of a Brahmanical origin, and admitting $(1935: 418)$ that there are no objective grounds for deciding between Jaina and Buddhist origins for the text, flatly states that he will proceed on subjective grounds. It is thus little surprise to find that the Japanese Buddhist scholar Kanakura eventually decides that the Praśnottararatnamālikā is indeed originally a (Mahāyāna!) Buddhist text (1935: 423). To reach this conclusion,

$56 \quad$ Pı: devam daivādhipam prathamam.

57 Variant: 'jam dpal ] G1, N1, $\mathrm{P} 1$ [all of which start here]:'phags pa 'jam dpal, that is, prefixing Ārya-.

$5^{8}$ Kanakura 1935: 399 also mentions the case of the Vajrasūci, transmitted as both a Buddhist and Hindu text, although in this case evidently borrowed from one tradition to the other. 
some gymnastics are involved, such as the rejection of the Tibetan colophon's plain meaning (see above, and in note 23), and the interesting claim (1935:421) that compared to the Buddhist text, the fact that the Vedantin version and the Jaina Prakrit text both contain additional verses leads to the conclusion that the Buddhist version alone is the original.

The contents of the text, in contrast to the trappings of praise at beginning and end, are entirely nonsectarian and generic. This situation changes with what I consider to be the additional verses found in some manuscripts (see Appendices 1 and 2), and in the editions of Śankkara's works. The historical core of the text, however, is without exception nonspecific. What emerges, therefore, is that one and the same text has Hindu, Jaina and Buddhist transmission lineages. In whatever milieu the text may have been actually composed-and, as above, there is virtually no evidence to decide this-it is clear that in its reception it was considered poly-sectarian, trans-sectarian or indeed even nonsectarian: as the property of all, it is the exclusive property of none.

\section{9}

\section{Editions and Translation}

In the Sanskrit edition below, I have not noted minor spelling variations, including several instances of confusion between $k h$ and $s$, missing vowel signs, omitted superscript $r$, geminations after $r$, and the like. In general, when the intention of the reading was clear, even if strictly speaking misspelt, I have not noted such errors in order to avoid cluttering the apparatus. In a few cases, when a reading is somewhat less than clear but nevertheless likely, I enclose the siglum in parentheses. When there are clear distinctions between variant readings, one of which corresponds to the Tibetan translation, I have tried to favor that reading in establishing the text. This does not imply any historical claim; rather, it is deployed as a useful means to establish the form of the text that may have stood closer to the Vorlage of the Tibetan translators. However, in quite a number of cases it was not possible to make decisions on this basis, and I have endeavored in each case to explain the choice between equally plausible readings, noting that the overall lack of context-each question and answer seems to be entirely independent of those preceding and following-renders decisions based on contextual logic moot. It is worth remarking that many readings yield unmetrical lines, and this is certainly a strong reason to reject them. ${ }^{59}$

59 With the exception of the first and last verses, the Tibetan is rendered in lines of 7 syllables. When necessary, I add a tsheg to clarify the metre even between syllables that are 
The translation renders the Sanskrit. Some manuscripts separate the questions and answers with a danda. Differences with the Tibetan rendering are generally noted when they seem significant. However, in the notes below, I have made no attempt to set the questions and their answers in the context of Indic literature more broadly. A number of instances of similar expressions in Indian gnomic literature could be adduced. Despite this general renunciation of the task of contextualizing the work more broadly, one exception is the above-mentioned Praśnottaramāla attributed to Śuka. This collection contains a number of expressions very close to those in our text, although it also contains quite a number of sectarian (generically Brahmanical) references, absent from our text (see Weber 1868:106-107). Given the proximity of some of its entries, I note a few of the parallels, taking cognizance of Weber's opinion that the work has modern origins.

The Sanskrit and Tibetan verses are independently numbered. I have followed the ordering of the majority of Sanskrit manuscripts, which on the whole agrees with the order of the Tibetan translation, but toward the end of the text some fluctuation occurs. Since the questions and answers follow no discernable order, it would have been easy for tradents to alter their ordering, and that has evidently taken place (see above for the extreme case of manuscript D). The numbering in the Tibetan edition follows the text in the Tanjurs, so that the original ordering should be clear to the reader, even when it diverges from that of the Sanskrit sequence, and I have had to rearraange the order of the Tibetan verse lines so as to align the two versions. I have further numbered the questions and answers. This numbering differs only slightly from that of Foucaux and Weber.

normally written together, typically $b a^{\prime}$. This is interesting in light of the observation of Hahn 2007: 306: "an āryā stanza is usually rendered by $4 \times 9$ syllables because only then is it possible to give a complete translation in which each Sanskrit word has a Tibetan equivalent." This is manifestly not the case in our text, with the exception of the first and last verses, as noted below. 
10.1

kaḥ khalu nālańkriyate

drșțāerșțārthasādhanapațīyān ||

kanțhasthitayā vimalapraśnottararatnamālikayā || $1 \|$

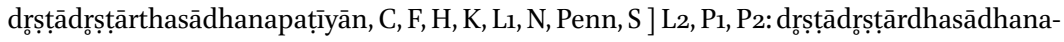
pațīyān; D: drsșțādrșțāarthasādhane pațīyān (unmetrical)

kanțhasthitayā vimala, C, K, L2, N ] P1: kam ca sthitayā vimala; H, P2: kamithasthitayā vimalā; D, F, L1, Penn, S: amuyā kaṇṭhasthitayā

Who, most clever in accomplishing his goals [in this world and the next, that is in the realm of the] visible and invisible, would not be adorned by this immaculate small precious garland of questions and answers, once memorized, as he would be adorned by a precious garland that sits around his neck?

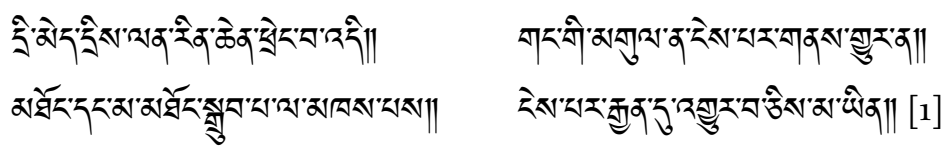

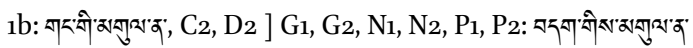

There is an evident double-meaning (śleșa) here, with the term kanțasthita signaling both memorization, that which one holds in the throat (we might say, 'keeps in mind,' or as I rendered, 'memorizes'), and a garland which lies around the neck. Note that although the Sanskrit metre is the same throughout, here the Tibetan uses a longer line of 9 syllables, as it does in verse 27 (Tibetan 4 ocd41ab). See above n. 59 . 
bhagavan kim upādeyam

guruvacanam heyam api ca kim akāryam |

ko gurur adhigatatattvah sattvahitābhyudyatah satatam || 2 ||

ca kim akāryam, D, F, H, K, L1, L2, N, P1, P2, Penn, S ] C (pc): kim yad akāryam adhigatatattvah, C, D, F, H, K, L1, P1, Penn, S ] L2: adhigatatatvā; N, P2: adhigatatat(t)vam sattvahitābhyudyataḥ, H, K, L2, P1] S: śișyahitāyodyataḥ; P2: satvahitābhyudyitaḥ; C (pc), D: satyahitāyodyataḥ; F, L1, N, Penn: satvahitāyodyatah

Lord, what is to be accepted? The speech of the teacher (1). And what, on the other hand, is to be rejected? Improper action (2).

Who is the teacher? One who has penetrated the truth, and constantly works for the benefit of beings (3).
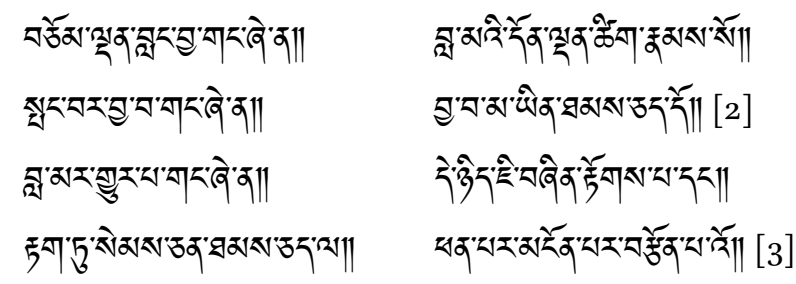

For $§ 1$, the Tibetan specifies that the teacher's speech is meaningful (don ldan). For $§ 3$, see Śuka §22 (verse 7): ko vā gurur? yo hi hitopadeștāa. In foot d, the reading with ${ }^{\circ} a b h i^{\circ}$ is supported by Tibetan mngon par, and sattva ${ }^{\circ}$ is supported by Tibetan sems can (thams cad = * sarva, not attested but to be understood as added for the metre and implied by the text). Note that in place of $s a t t v a^{\circ} \mathrm{S}$ has śisya ${ }^{\circ}$.

10.3
tvaritam் kim kartavyam viduṣā samiāarasantaticchedah |
kim mokṣataror bïjam samyagjñānam kriyāsahitam || 3 ||

viduṣā, F, H, K, L1, L2, N, P1, P2, Penn] S: viduṣām; C, D: sudhiyā samsārasantaticchedah, C, D, F, K, L2, N, P1, Penn, S ] H: saṁāāasamtataḥ bedaḥ; L1: samsārasamitatibbedaḥ; $\mathrm{P}_{2}$ : sam̄āāasamtatibedah (unmetrical) kriyāsahitam, C, D, H, K, L1, L2, F, P1, P2, Penn ] S: kriyāsiddham 
What must a wise man do urgently? Cut off the continuity of the cycle of transmigration (4).

What is the seed of the tree of liberation? Correct knowledge joined with [appropriate ritual] action (5).
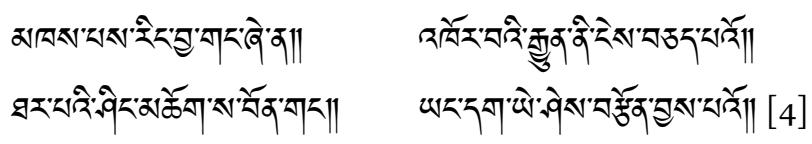

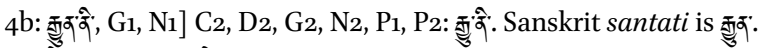

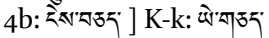

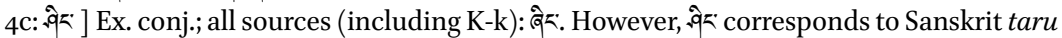
(this emendation was already pointed out by Foucaux 1867: 71n2).

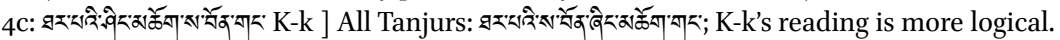
Kanakura 1935: 432n is puzzled by the Tanjur reading, as indeed he should be, and appears ignorant of Foucaux's correction.

Note that in Tibetan $4 \mathrm{~d}$, brtson byas pa'o does not seem to correspond at all to kriyāsahitam. I do not understand this.

10.4

kim pathyataram dharmạ

kaḥ śucir iha yasya mānasam śuddham |

kah paṇ̣ito vivekī

kim viṣam avadhīraṇaṁ guruṣu || 4 ||

I begins with panditito

kim pathyataram, F, L1, Penn ] H, K, L2, P1, P2: kim pathyadanam;; D: kim pathyatamam; C,

$\mathrm{N}, \mathrm{S}$ : kah pathyataro. This reading may have been attracted by the gender of dharma. kah śucir iha, C, D, F, H, K, L1, L2, P1, S] P2, Penn: śucir iha; N: śucir iha yasya mānasam śuddham, C, D, F, H, K, L1, L2, N, P1, Penn, S ] P2: mānasam śuddham avadhīraṇam guruṣu, D ] S: avadhīraṇā guruṣu; I, N, Penn: avadhīritā guravaḥ; P1, P2: ava-

dhāritā guravaḥ; C, F, H (pc), K, L1: avadhīritā guravaḥ; L2: avadhīritā guravā. Note that in verse $17 \mathrm{c}$, when the word avadhirana occurs there are no variants.

What is of the greatest benefit? Dharma (6). Who, here [in the world] is pure? One whose mind is pure (7).

Who is a sage? The discerning one (8). What is poison? Disrespecting the teachers (9). 


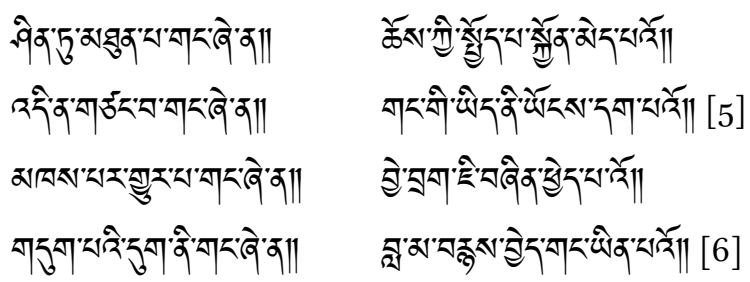

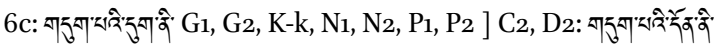

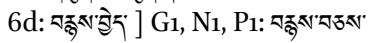

For $\S 6$, Tibetan has "faultless practice of dharma." With regard to $§ 9$, Garrez 1867: 506n1 writes "Avadhïray s' emploie dans le sens de ne pas se conformer aux paroles de quelqu'un," and further refers to the expression duradhìtā vișaì vidyā in Cāṇakyanitiśâstram 98 (found also in Prajñādaṇda 10, attributed to Nāgārjuna, Hahn 20o9: 14). For $§ 9$, as Harunaga Isaacson points out, the reading of D (cf. S), avadhiraṇam guruṣu, means "disrespecting the teachers," but avadhiritā guravah (in I, N, Penn, and implied in C, F, H (pc), K, L1, L2) means rather "disrespected teachers," that is, as he explains, "the teachers themselves, if disrespected, will be poison for one, that is to say, will harm one." As I believe that the Tibetan bla ma brnyas byed is closer to the former reading, I adopt it here.

10.5

kim samiāre sāram

bahuśo 'pi vicintyamānam idam eva |

manujeșu drș̣țatattvam

svaparahitāyodyatam janma || 5 \|

Omitted in N.

kim samsāre sāram, D, H, (I), K, L1, L2, P1, P2, Penn, S ] F: samsāre kim sāram்; C: saṁsāre kimm asāre

bahuśo 'pi vicintyamānam idam eva, D, F, H, (I), K, L1, L2, P1, P2, Penn, S ] C: bahudhā samcetya sāram idam eva

manujeșu dṛștatattvami: spelt generally manujeșu drsștatatvam, F, H, I, K (kha), L1, L2, P1, Penn ] C, P2: manujeșu drsșțitatvam; K (ka) manujeșu drsșțasattvam; D: manujeșu drsștatatvam kim; S: kim manujeșv ișțatamam

svaparahitāyodyatam, D, F, H, (I), K, L1, L2, P1, P2, Penn, S ] C: kim svaparahitāyodyatam

What is the pith in the world of transmigration? No matter how much one thinks about it, it is just this:

Birth as a human, in which truth has been seen and in which one strives for the benefit of self and others (10). 


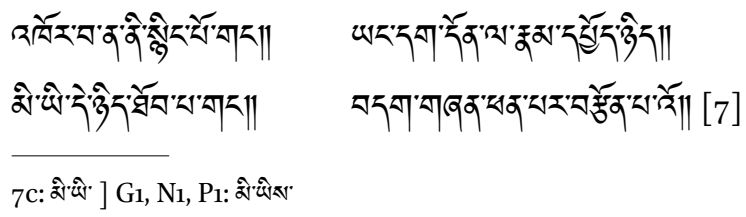

The Tibetan translation assumes two questions, answering the first in $7 \mathrm{~b}$ with something like "Precisely contemplating the ultimate truth." The reading in $\mathrm{S}$ of Sanskrit $5 \mathrm{c}$ is "What is most desirable among men?" This leaves the referent of idam unclear, and might be an emendation of the editors of $\mathrm{S}$ or some source of theirs. It is difficult to correlate any of the attested Sanskrit readings with Tibetan thob. Against the choice made here, there is in any event nothing in Tibetan corresponding to drșta, although it is likely that we should see

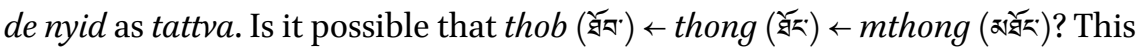
would give us an equivalent of drsța. Tibetan as we have it seems to mean: "Who obtains the Truth of/among men? One who exerts himself for the benefit of self and others."

10.6

madireva mohajanakah

kaḥ snehạ̣ ke ca dasyavo viṣayāḥ |

kā bhavavallī troṣnā

ko vairī nanv anudyogah $\|6\|$

ke ca dasyavo vișayāḥ, (C), D, F, H, (I), K, L1, L2, N, Penn, S ] P1: ke va dasyaśe viṣacyāḥ; P2: ke vidasyavo viṣayā

kā bhavavallī trọṣnā, D, F, H, K, L1, L2, N, P2, Penn, S ] P1: kā namavallī trọmā; I: kā bhavavallī māyā

nanv anudyogaḥ, C, K ] L2: nanv anudyogāḥ; P2: nanv anuṁyogaḥ; H: nanv anuyogaḥ; D, F, L1, Penn, S: yas tv anudyogah; N: yo hy anuyogyam; I: damaged; P1: tanv a - - - .

What produces stupor, like strong drink? Attachment (11). And who are thieves? Sense objects (12).

What [grows swiftly and aggressively like] the vine [that leads one to cling to] existence? Lust (13). Who is the enemy? None other than laziness (14). 

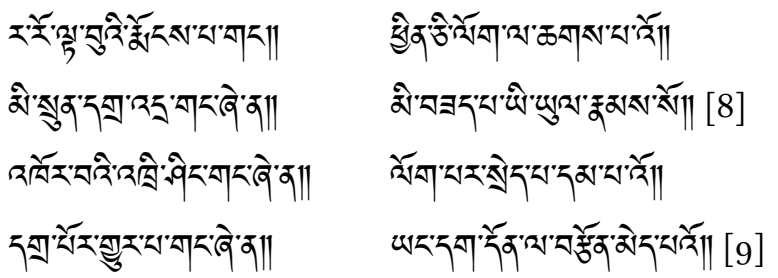

For $§ 12$, see Śuka $§ 79$ (verse 25): ke dasyavaḥ santi? kuvāsanākhyāḥ. My translation of $\S 13$ is a clumsy attempt to bring out what I see as the image of the creeper, the clinging of which is apparently central here. Prof. Deshpande suggests that the image may be of one shoot growing out of another continuously. Tibetan understands the answer as "devotion to perverse desires." Somewhat distantly, for $§ 14$, see Śuka $§ 16$ (verse 5): jivvan mrtah kas tu? nirudyamo yah. Tibetan understands here "lack of energy directed toward the truth." 60

kasmād bhayam iha maraṇād andhād api ko viśișyate rāḡi | kah śūro yo lalanālocanabāṇair na vivyathitah || 7 ||

andhād api, (C), D, F, H, K, L1, L2, P2, Penn ] S: andhād iha; P1: vaṁdhāv api; N: annād api; I: damaged.

ko viśișyate rāgī, C, D, F, H, K, L1, L2, N, P2, Penn, S ] P1: ko citoyato rāgī; I: damaged. na vivyathitah, F, L2 ]; C: na vivyathite; H, K, L1, Penn, W (emending F): na ca vyathitah; P1, S: na vyadhitah; D: na ea vyadhitah; P2: na ca vyadhitah; N: vyathitahṛdayo naḥ; I begins with ///dhitah on $166^{\mathrm{r}}{ }^{1}$. Szántó suggests that the original $v i^{\circ}$ lost its vowel, and was then either read as or emended to $c a$.

6o After commenting that Foucaux's edition, by altering the sandhi of the original, which he did not recognize to be in verse, "disfigures" the text, Garrez 1867: 504 goes on (without, of course, knowing of the existence of the reading I have adopted, nanv anudyogah): "Cette ... erreur a excercé une influence fâcheuse sur la traduction française. Ainsi le §14 est rendu: "Qui est un ennemi? Celui qui ne fait aucun effort (yas tvanudyogah)." Il fallait traduire, sans se préoccuper de la tournure relative, qui n' est employée ici que pour le mètre: Quel est l' ennemi? Le manque d'énergie. On obtient ainsi, au lieu d'un non-sens, une idée familière aux poëtes indiens." He then refers in a note to a passage from Bhartroari (he calls it II.74), which I believe to be the following (Kosambi 2000: 86, verse 216):

àlasyaì hi manusyānāàm śarīrastho mahāripuḥ|

nāsty udyamasamo bandhụ krtvā yam nāvasīdati

This is rendered freely by Kennedy 1913: 79 (verse 86 for him) as: "Mankind's great enemy is idleness. There is no friend like energy, and if you cultivate that you will never fail." 
What does one fear here [in the world]? Death (15). Who is in a worse situation than even a blind man? A lustful one (16).

Who is a hero? One not brought down by the arrows that are the sideways glances of a woman (17).
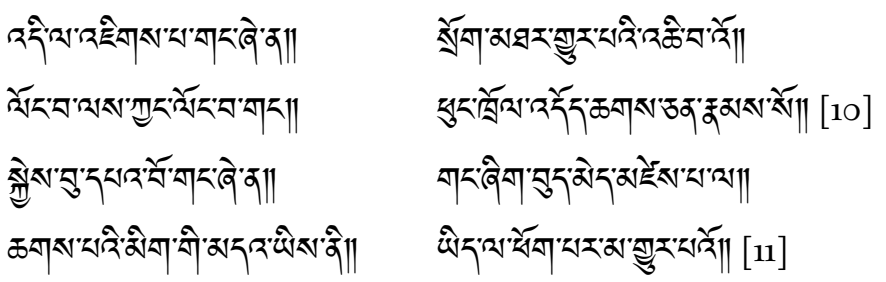

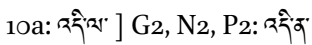

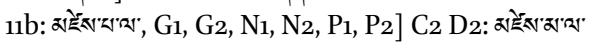

For $\S 16$, Tibetan has "Those (plural!) possessing attachment to vain things." See here also Śuka $\S 20$ (verse 6): ko janmanāndho? madanāturo yo. For $\S 17$, see Śuka $\$ 41$ (verse 12): śūrān mahāśūratamo hi ko vā? manojabānair vyathito na yas tu.

Regarding the reading viryathita, it may be that the image of the arrow attracted the reading vyadhita, which however is evidently an incorrect form of what should be viddha. However, note that Tibetan phog par ma gyur pa might well render na viddha, and therefore conceivably reflects the reading vyadhita.

10.8

pātum karṇāñjalibhih

kim amrtam iva yujyate sadupadeśą̣ |

kim gurutāyā mūlam

yad etad aprārthanami nāma || 8 ||

iva yujyate, C, D, F, L1, Penn ] S: iha yujyate; K, L2, N, P1: iva budhyate; H, P2: iva pīyate; I: damaged

gurutāyā mūlam, D, F, H, I, K, L1, L2, N, P1, P2, Penn, S ] C: guruvāyām utpam

aprārthanam, D, F, H, I, K, L1, L2, N, P1, P2, Penn, S ] C: arthātham

What is suitable to be drunk as nectar with one's ears as cupped hands?

The teachings of good persons (18).

What is the basis of exaltation? Not asking for anything at all (19). 

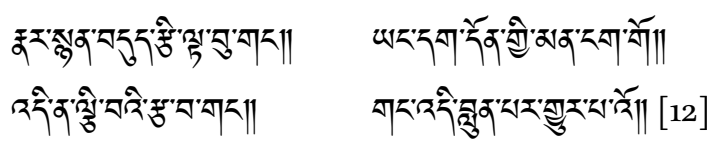

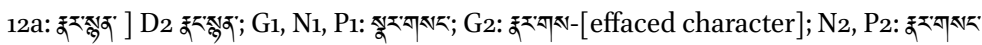

Regarding foot a, a verse with its key word is found in the Bhāgavatapurāna: 3.13.51:

ko nāma loke puruṣārthasāravit purākathānām bhagavatkathāsudhām | āpīya karṇāñjalibhir bhavāpahām aho virajyeta vinā naretaram ||

The "teachings of good persons" may also be simply "good teachings."

For $§ 19$ and $\S 23$ below, see Śuka $§ 5^{8-59}$ (verse 18): sadä laghutvaí ca kim? arthitaiva. gurutvam asyaiva viparyayo 'sti. There is a pairing of $\S 19$ 's gurutā with lāghu in $§ 23$. Tibetan lci ba understands guru here as something like weightiness. Schiefner 1858: 19, item 20, understood Tibetan 12cd as: "Wer hat hieselbst die Wurzel der Schwere? Derjenige, der dumm ist." There is no remark by either Foucaux or Kanakura. I cannot very well imagine what the Tibetan translators read in their Vorlage of the Sanskrit 8d. Sanskrit pra $\sqrt{a r t h}$ is generally rendered by bslangs $p a$, such that ma bslangs = aprārthana, but I cannot imagine how this might have become blun pa.

kim gahanam strīcaritam

kaś caturo yo na khạ̣ditas tena |

kim dāridryam atoṣạ

evami kim lāghavaṁ yācñā || 9 \|

feet cd absent in C, D.

khaṇditas tena, C, D, F, H, I, K, L1, L2, P2, N, Penn, S ] P1: khaṇḍitaseṭha

kim dāridryam atoṣah, F ] N: kim dāridryam asantoṣa; P1: kim dāridragam amitoṣaḥ; L2, P2: kim dāridram asaṁtoṣa; Penn: kim dāridryam asaṁtoṣaḥ; H: ac: kim dāridryam asamtoṣa, pc: kim dāridram asaṁtoṣa; K, Lı: kim dāridrayam asamitoṣa; I: kim dāridam asantoṣam; S: kim duḥham asamtoṣah

evam kim lāghavaṁ yācñā ] K: eva kim lāghavam yācñā; N: eva kim lāghavā yācñā; F: kim laghutāmūlakam yāñcā; P1: evam kim lāghavam yācā; L2, P2: eva(m) kim lāghavam yāñjā; Lı: eva kim ca lāghavam parayāmincnā; Penn: kim ca lāghavam parayāmincyā; H: eva kim lāghavam ca yācñā; I: evamim lāghavam parayācyā; S: kim lāghavam adhamato yāñ $\bar{a}$ 
What is a impenetrable forest? The behavior of women (20). Who is clever? The one who is not torn to pieces by that [behavior] (21). What is poverty? Just dissatisfaction (22). What is humiliation? Begging (23).

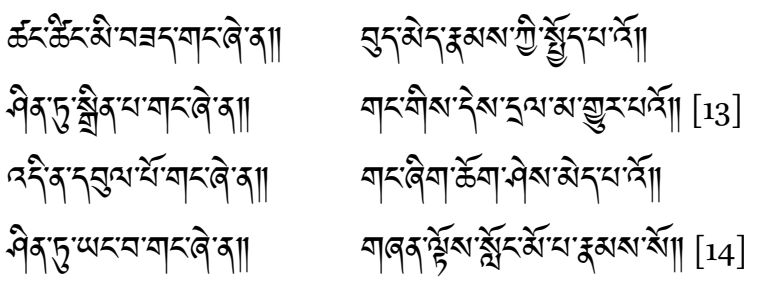

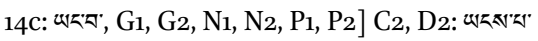

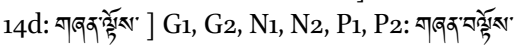

The reading of cd is highly problematic, and while what I print is metrical, I am not at all sure about it. For $§ 20$, see Śuka $\S 53$ (verse 16): jñātum na śakyam hi kim asti sarvair? yoșinmano yac caritam tadīyam. For § 21, see Śuka $\S 42$ (verse 12): präjño 'tidhïraś ca samasti ko vā? prāpto na moham lalanākațākșaih. For §22, see Śuka §14 (verse 5): ko vā daridro? 'tiviśâlatrṣnạ. Tibetan seems to have had something like *iha ('di $n a$ ). For $§ 23$, see above under verse 8 .

kim jīitam anavadyam

kim̉ jāḍyam pāțave 'py anabhyāsaḥ |

ko jāgarti vivekī

kā nidrā mūḍhatā jantoḥ || 10 ||

C has after verse 12 .

kim jāọyam pāțave py anabhyāsaḥ C, F, H, K, L1, L2, P2 ] S: kim jāḍyam pāțhato 'py anabhyāsaḥ; D: kim jāḍamam pāṭave py anabhyāsaḥ; P1: kim tā-pāṭave py anuvyāsaḥ; Penn: kim jāḍūyam pāṭave py anabhyāsaḥ; I: kim jāḍamam pāṭhane 'py asah; N: kim jāḍyam pāțhikeșv anabhyāsah

ko jāgarti, D, F, I, K, L1, Penn, S ] H, N, P1: ko jāgaro; C, L2: ko jāgarī; P2: after jāga, one leaf is missing.

vivekī, C, F, H, I, K, L1, L2, P1, Penn, S ] D: virāgī; N: vivekah

mūḍhatā jantoḥ, C, D, F, K, L1, L2, N, P1, Penn, S ] H: mūḍhatām jamito; I: mūḍhatā jātā jantoh 
What is [correct] livelihood? [A livelihood that is] irreproachable (24). What is sluggishness? Not practicing even when one has acuity (25). Who is [truly] awake? One who discriminates [correctly] (26). What is sleep? The confused state of a person (27).
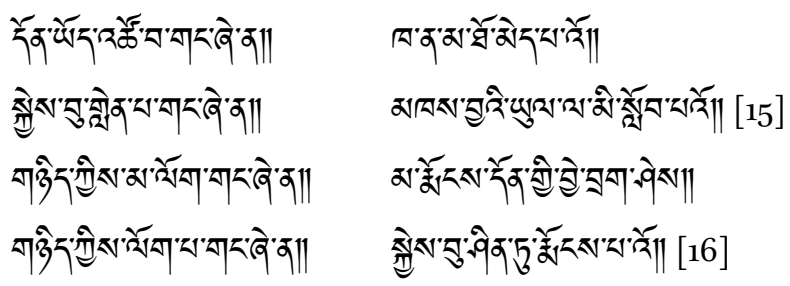

Tibetan mkhas bya (15d) is related to $\sqrt{ }$ paț. For $\S 24$, see Śuka $\S 36$ (verse 11): kim jivvanam? doșavivarjitam yat. Tibetan understands the question as "meaningful livelihood." For $§ 25$, Tibetan has: "not practicing what one is skilled at / in the domain in which one should be good." For § 26 , see Śuka §11 (verse 4): jāgarti ko vā? sadasadvivekí. It may be that jāgaro vivekah goes better with nidrā (and the Prakrit of Pavolini 1898 has kojāgaro), but if so this is a minority reading.

10.11

nalinīdalagatajalavat taralam kim yauvanam dhanam cāyuh |

ke śaśadharakaranikarānukāriṇaḥ sajjanā eva || 11 ||

nalinīdalagatajalavat taralam, F, S ] D, H (pc), I, K, L1, L2, Penn: nalinīdalagatajalalavataralam; Pı: nalinīdalagatajalam iva taralam; N: nalanīdalagatajalavat taralam; C: nalinidalajalataralam, followed by kim kim kim (!)

dhanam cāyuh, C, (I), L1, Penn, S ] F, H, K, L2: dhanam athāyuḥ; P1: dhananadhātụ̣; D: dhanam jāyāḥ

ke śaśadharakaranikarānukāriṇah, F, H, I, K, L1, L2, N, P1, Penn ] S: kathaya punaḥ ke śaśinaḥ kiraṇasamāḥ: D: ke śaśadharasya kiraṇānukāriṇaḥ; C: ke śaśadharakaranikaropakārinah (the Prakrit in Pavolini 1898 reads the line: ke sasaharakaraniyarā uvayārino sajjạnā evaim)

What quivers in transience like a drop of water on a lotus petal? Youth, wealth and lifespan (28).

Who are like the mass of moon-beams [in giving relief]? Only the virtuous (29). 

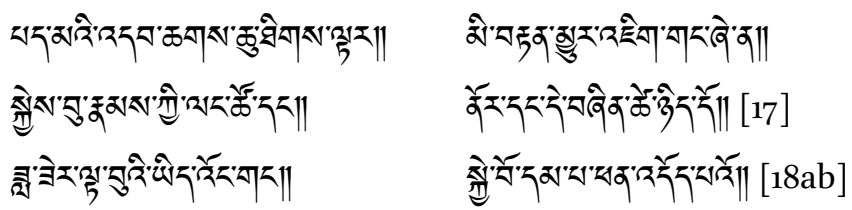

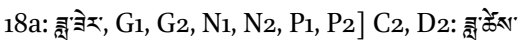

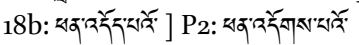

Quoted in the anthology Śärngadharapaddhati, dating to 1363, with the reading nalinïdalagatajalalavataralam (Peterson 1888 : 88 , verse $557^{61}$ ). Harunaga Isaacson point out that the Mohamudgara (popularly Bhaja Govindam), attributed to Śan்kara, reads in 4ab: nalinīdalagatajalam atitaralam tadvajjivitam atiśayacapalam.

Regarding the reading of our text, the evidence of the Tibetan is a bit ambiguous: Itar certain supports ${ }^{\circ}$ vat, but tshig supports lava. The reading of $\mathrm{P}_{2}$ in $18 \mathrm{~b}$, phan'dogs pa, might agree with the Prakrit uvayārino in representing *upakāra, which is in fact the reading in Sanskrit manuscript C. Tib. 18a seems to mean, "what is pleasing like moon-beams?", while $18 \mathrm{~b}$ seems to mean "good people who wish to benefit others." For § 28, see Śuka § 91 (verse 29): vidyuccalam kim? dhanayauvanāyur. (For vidyut, see §59, below.)

10.12

ko narakaḥ paravaśatā

kim saukhyam sarvasangaviratir yā |

kim satyam bhūtahitam

priyaṁ ca kim prāṇinām asavaḥ || 12 ||

kim satyam bhūtahitam், D, H, K, L2, P1, S ] I: kim sātyam bhūtahitamं; F, L1, Penn: kim sādhyam bhūtahitam; $\mathrm{N}$ : kim pathyam bhūtahitam; C: samsāre niḥsāre

priyam ca kim prāṇinām asavah, S ] L1, Penn: kim priyam prāṇinām asavaḥ (unmetrical); I: kim priyam ca prāṇinām asavah (unmetrical); P1: kim preyah prāṇinām asamaḥ; C: kim priyam prāṇinām aśmavah (?); F, H, K, L2: kim preyah prāṇinām asavaḥ; D: kim priyam iha jīvinām asavaḥ; N: kva prema ṇāṇinām asavaḥ

What is hell? Being subject to the control of another (30). What is pleasure? Disinterest in every sort of attachment (31).

What is truth? Benefitting creatures (32). And what is dear to beings? Life (33).

61 And on this basis also in the modern Subhāṣitaratnabhāṇ̣̂āgāram, Āchārya 1952: 171, vs. 790, and elsewhere. 


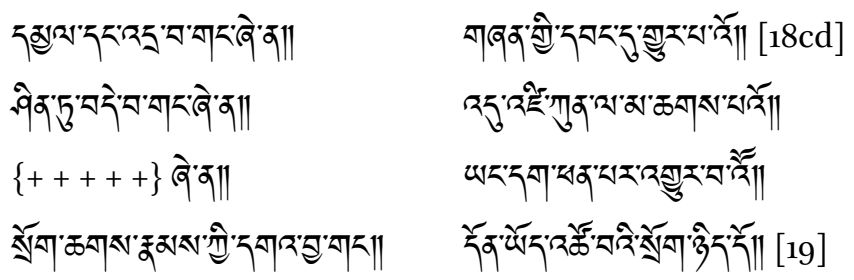

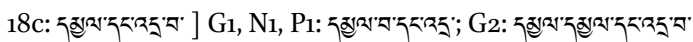
19cd: Only in the Khara-khoto Ms; see discussion in the Introduction above. I have added the tsheg between $b a$ and 'o for the metre; it is not written in the manuscript.

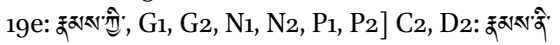

As an example of the sort of parallels one might identify elsewhere in Indian literature, in addition to the verse cited above in note 57 , for $\S 31$ see perhaps again Bhartrhari's Epigram (Kosambi 2000: 154, §468a): kim asukham präjñetaraị samgamah For virati, Tibetan suggests "nonattachment." Tibetan understands the answer to $\S 33$ as "a meaningful life."

kim dānam anākān̉kṣam

kim mitram yan nivartayati pāpāt ||

ko 'lañkārah śîlam

kim vācām maṇḍanam satyam || 13 ||

For $\mathrm{C}$ this comes after verse 16 ; in $\mathrm{S}$ this is $\# 22$.

anākān்kṣam, C, D, F, H, K, L1, L2, N, S ] P1: anāmkāmiłṣ̣am; Penn: anākāmasṣyam;; I: anākān̉kșā

kim mitram, C, F, H, I, K, L1, L2, P1, S ] D: tīrtham kim; Penn: mitram

yan nivartayati, D, N, P1 ] C, F: yan nivārayati; H, K, L1, L2, P2 (resumes here), Penn: yan nivārt(t)ayati; I: yo nivārayati. Tibetan zlog byed would seem to support connection either with $n i \sqrt{v r}$ or $n i \sqrt{ } v_{0} t$.

What is generosity? [A gift] without expectation [of any return] (34).

Who is a friend? One who restrains one from evil (35).

What is the ornament [of life]? Restraint (36). What is the adornment of speech? The truth (37). 


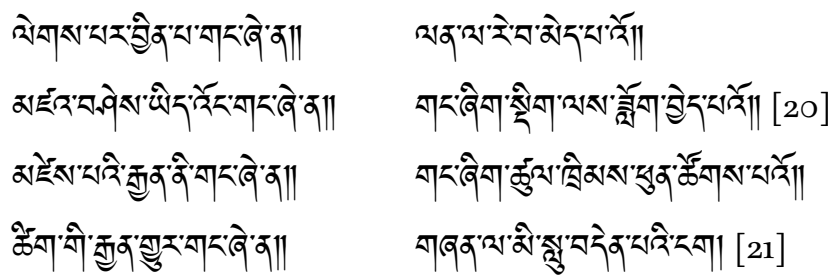

20a: G2, N2, P2 skip from the end of verse 19 to $24 a$.

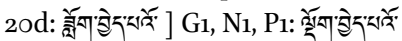

Tibetan in 21d understands: "Speaking truthfully to others."

kim anarthaphalami mānasam asaṁyatam kā sukhāvahā maitrī | sarvavyasanavināśe ko dakṣaḥ sarvathā tyāgī || 14 ||

kim anarthaphalam mānasam asamyatam, C, D, F, N ] S: ko 'narthaphalo mānạ̣; H, K, L2, P1: kim anarthaphalam mānasam asamgatamं; P2: kim anarthaphala mānasam asamgatam; Lı, Penn: kim anarthaphalam mānaḥ susamgati(h); I: kim anarthaphalam mānaḥ susam///. Tibetan ma bsdams pa supports asaimyata.

kā sukhāvahā maitrī, C, D, F, H, K, L1, L2, N, P1, Penn] S: kā sukhadā sādhujanamaitrī; P2: kā sukhādahā maitrī; (I: /// hā maitrī)

sarvathā tyāgī, D, S ] P2: sarvvathā tyāgīḥ; F, I, L1, Penn: sarvarthā parityāgī (unmetrical, hence W: read metri causa sarvaparityāgī); P1: sarvaprātyāgaḥ; $\mathrm{H}, \mathrm{K},(\mathrm{L} 2$ ?): sarvathā tyāgaḥ; N: sarvadā tyāgaḥ; I: sa???ā parityāgī; C: yo sarvadā tyāgī.

What results in disasters? An unrestrained mind (38). What confers pleasure? Friendliness (39).

Who is adept at destroying all addictions? One who is in every respect a renunciant (40).
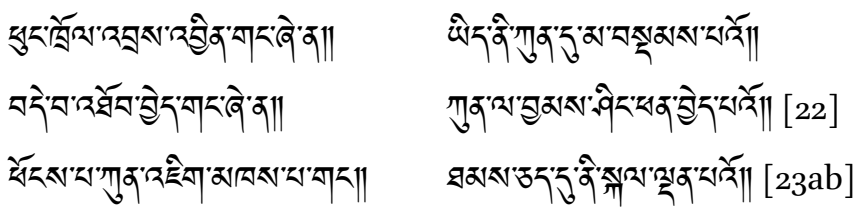

23b: See the discussion above 
Sanskrit anartha is rendered with phung khrol, as in Bodhicaryāvatāra viII.40.

For the Tibetan correspondent to tyāg $\bar{\imath}$, see the discussion in the Introduction, above. Although tyāga might be a better reading (What is adept at destroying all addictions? Renunciation in every respect), the Tibetan skal ldan pa suggests the unattested *bhägin, but in any event therefore the possessive suffix, ${ }^{\circ}$ in.

ko 'ndho yo 'kāryaratah

ko badhiro yah śrnọoti na hitāni |

ko mūko yaḥ kāle

priyāṇi vaktumi na jānāti $\| 15$ ||

In $C$, after verse 22 ; for $S$, this is \#21.

yaḥ śrnọoti na hitāni, C, D, F, H, I, K, L1, L2, N, P1, P2, Penn ] S: yo hitāni na śrṇoti

kāle priyāṇi, C, D, F, H (pc), I, K, L1, L2, N, P2, Penn, S ] P1: kāli divyāṇi

Who is blind? One who delights in what is wrong (41). Who is deaf? One who does not listen to what is beneficial (42).

Who is dumb? One who does not know to speak agreeably at the appropriate time (43).
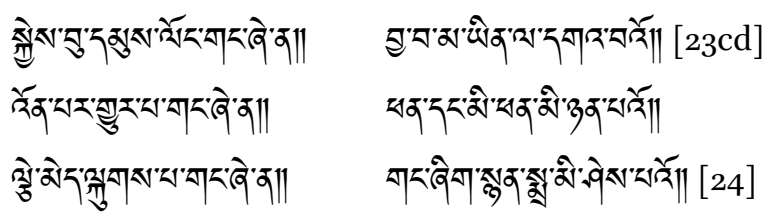

For $§ 42-43$, see Śuka §62-63 (verse 19): mūkaś ca ko vā vadhiraś ca ko vā? vaktum na yuktam samaye samarthah tathyam sa pathyam na śrnoti vākyam. For $§ 42$, Tibetan has: does not listen to the beneficial and unbeneficial. 
10.16

kim marạ̣am mūrkhatvam

kim cānarghyam yad avasare dattam |

à maraṇāt kim śalyam

pracchannam yat krtam akāryam || 16 ||

kim maraṇam, C, D, F, H, I, K, L1, L2, N, P2, Penn, S ] P1 (ac): kim maprā(?)raṇam்; P1 (pc) jim maprā(?)raṇam

kim cānarghyam yad avasare, C, D, F, H (ac), I, K, L1, L2, Penn ] S: kim cānargham yad avasare; P2: kim cārghyam yad avasare; $\mathrm{H}$ (pc): kimm anarghyam yad avasare; P1: - - - - - re; N: kim cānargham yad etad avasare

ā maraṇāt, D, F, H, I, K, L1, L2, N, P1, P2, Penn, S ] C: ābharaṇāt

pracchannam yat kratam akāryam, F, H, K, L2, P2 ] P1: - lam ya krıtam akāryam; D, I, L1, Penn, S: pracchannam yat kṛtam pāpam; $\mathrm{N}$ : pracchanne yat kṛtam akāryam; C: pracchinnam yat krtam akāryam

What is death? Foolishness (44). And what is priceless? What is given in the right situation (45).

What is a thorn tormenting until death? The forbidden act performed secretly (46).

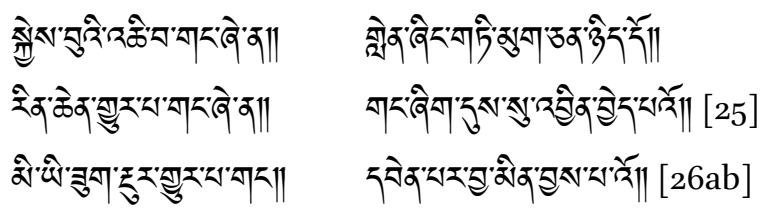

Tibetan bya min is equivalent to akārya, also supported by the Prakrit version's akajjaim, not the alternative reading pāpa. 


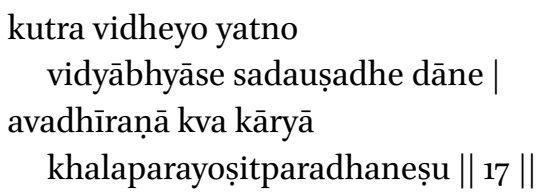

kutra, C, D, F, H, I, K, L1, L2, N, P2, Penn, S ] P1: atra

vidyābhyāse sadauṣadhe, C, D, F, H, I, K, L1, L2, P2, Penn, S ] I: vidyā vidyābhyāse sadaușadhe; P1: vidyā —ro sadoșathe; N: vidyābhyāse sadauṣadhī

dāne, D, F, H, I, K, L1, L2, N, P1, Penn, S ] C: dyane

khalaparayoșitparadhaneșu, D, F, H, K, L2, N, P2, Penn, S ] P1: khalakhalaparayoṣitparadhareșu; I: khalaparayoṣitparanveșu; Lı: khalaparayoșitparasveșu; C: khalaparayoṣitaparasveșu

Where is effort to be exerted? In repeated study, in [searching for] true remedies, and in giving (47).

What should one avoid? The badly behaved, another's wife and another's wealth (48).

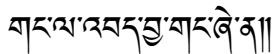

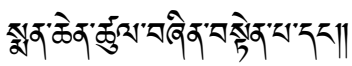

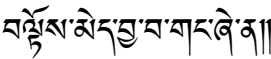

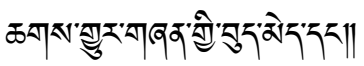

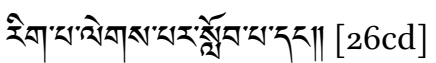

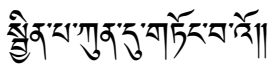

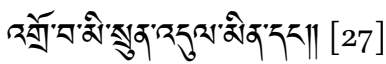

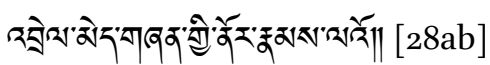

10.18

kāharniśam anucintyā
samisārāsāratā na tu pramadā |
kā preyasī vidheyā
karuṇā dākșiṇyam api maitrī || 18 ||

Feet cd absent in D.

kāharniśam, C, D, F, I, K, L1, L2, N, P1, Penn, S ] P2: kā 'harniśim; H: kāharniśim; N (ac): kā 'hīrniśam

na tu pramadā, F, I, L1, N, Penn, S ] D, H, K, L2, P1, P2: na ca pramadā

karuṇā dākṣiṇyam api, H, K, L2, N ] P1: kasaṇā dākṣinyyam api; P2: karuṇā dākṣiṇya 'm apya; F: karuṇā dākșiṇyam atha [this is Prakrit aha, in the phrase karuṇa dāhiṇnam aha]; I, Penn, S: karuṇā dīneșu sajjane; Lı: karaṇā dīneșu sajjane; C: karuṇād dākṣiṇyam sajjane 
What should one contemplate day and night? The vanity of transmigration-but not women (49).

What is to be considered dearest? Compassion, kindness and friendliness $\left(5^{\circ}\right)$.
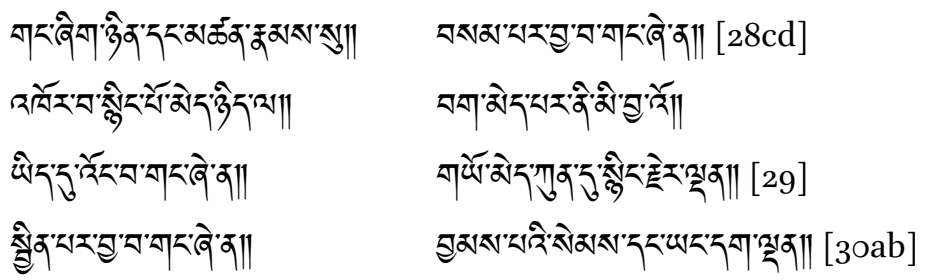

For $§ 49$, see Śuka $§ 99$ (verse 31): aharniśaṁ kiṁ paricintañ̄yaṁ? saṁsāramithyātvaśivātmatattvam. In $\S 5$ o, Tibetan has "possessing unshakable universal compassion." In Tibetan 29b, bag med pa is evidently a mistranslation, as pointed out by Kanakura 1935: 438n, reading pramāda (without case ending?) instead of pramadā. Tib. makes a question out of zoa: "What should be given" ("kā preyasīva deya?). 3 ob suggests something like *maitri-samanvitam/samyuktam. There is evidently a significant variation here from the available Sanskrit text.

kaṇțhagatair apy asubhị

kasyātmā no samarpyate jātu |

mūrkhasya viṣādasya ca garvasya tathā krrtaghnasya || 19 ||

kaṇṭhagatair apy asubhị̣, C, D F, H, I, K, L1, Penn, S ] P1: kam vyāvair apy astutiḥ; L2: kaṇțhagatair apy aśrubhiḥ; P2: kamțhagatair a'pyam śubhị

kasyātmā no samarpyate jātu, K, L2, Commentary in Vimalabodhi Vijayu 2005 ] F, N: kasyātmā nopasarpyate jātu; W: kasyātmā nopasarpate jātu (suggesting F's nopasarpyate is rather nopasarppate); S: kasya hy ātmā na śakyate jetum; Pı: kasyātmā no vā aryyate jamitoḥ; P2: kasyā 'tmā no na sammarpyate jamtuḥ; H: kasya mano na samarpyate yat tu; I, L1, Penn: kasyātmā na vaśam upayāti; D: kasya mano na vaśatām yāti; C: kasya mano na vaśyatām yāti

mūrkhasya, D, F, H, K, L2, P1, P2, S ] I, L1, Penn: mūrkhasyā

vișādasya ca garvasya tathā krrtaghnasya, F, H, K, L2 ] P1: viṣādasya ca garvasya bhavākrọtaghaṇa; D: vișādavato €a garvavato vai tathā krtaghnasya; P2: viṣādasya garvasya tathā krrtaghnasya; I, Lı, Penn: śan̉kitasya viṣādavatạ̣ kṛtaghnasya; S: śan̉kitasya ca viṣādino vā kṛtaghnasya; $\mathrm{N}$ : vipannasya garvasya tathā kṛtaghnasya; C: vișādavato garvavato vai krtaghnasya 
To what should one never give oneself over, even at the point of death?

To a fool, and to despondency, to pride and to an ungrateful person (51).
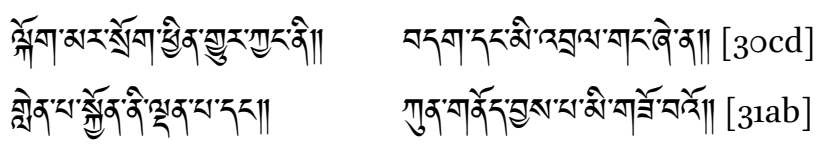

For § 51, see Śuka §56 (verse 17): vāso na saṁgah saha kair vidheyo? mürkhaiśca pāpaiś ca khalaiś ca nicaih. The incredible instability of the readings in foot $\mathrm{b}$ illustrates the tradition's uncertainty of the intended sense here. For invaluable suggestions about this verse I am in debt to Harunaga Isaacson.

kah pūjyah sadvrtttạ

kam adhamam ācakșate calitavrrttam |

kena jitam jagad etat

satyatitikṣāvatā pumsā || 20 ||

kaḥ pūjyaḥ sadvróttaḥ, F, H, I, K, L1, L2, N, P2, Penn ] S: kaḥ sādhuḥ sadvṛttaḥ; P1: vā ajyaḥ sadvrittah; D: kah pūjyah sādhuh sadvrorttah; C: sadvrtah

adhamam, D, F, H, I, K, L1, L2, N, P2, Penn, S ] P1: adhagam; K: adhanam; C: atham

calitavrttam, C, D (pc), F, H, K, L2, N, P2 ] D (ac), P1: calitam vrottam; L1, Penn, S: tv asadvrottam; I: ca sa vrttam

jagad etat, C, D, F, H, I, K, L1, L2, N, Penn, S ] P1: jatahe tadā; P2: gajad etat

satyatitikșāvatā pumsāa, F, L1, L2, N, Penn, S ] P1: satyativikṣayatām pumsām; P2: satyatitikṣāvatā puṁāḥ; H: satyatitikṣāvatā pumsām; I: satyadhuti?titikṣāvatā pumsāmi; D: satyatitikṣāvatām pumsām; C: satyatitikṣavavā pusā

Who should be honored? One of good conduct (52). Whom do they declare to be vilest? The one whose conduct has deviated [from the right course] (53).

By whom is this world conquered? By a man possessed of truth and patience (54). 


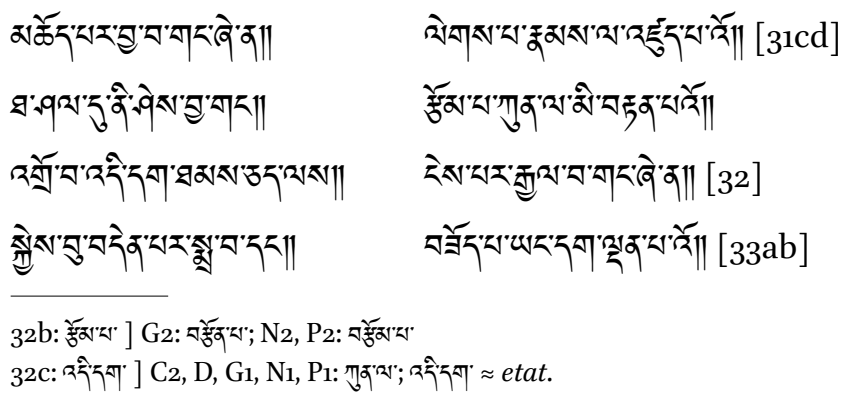

kasmai namaḥ surair api sutarām kriyate dayāpradhānāya |

kasmād udvijitavyam samisārāraṇyataḥ sudhiyā || 21 ||

namah surair api sutarām kriyate, C, D, F, H (pc), K, L2, P2 ]; P1: namah surair api śuta samkriyate; Lı, Penn: namaskriyā syād devānām api ca; I: namā?ki yās?ā dedavānām api ca; S: namāmsi devāḥ kurvanti; N: namaḥ surair api niratām kriyate; api is supported by गुर:

dayāpradhānāya, C, F, H, K, L2, P1, P2, S ] I, L1, Penn: dayāpradhānasya; D: dayāpradhānāyā; $\mathrm{N}$ : yadāpradhāno yah

udvijitavyam, C, F, H, K, L2, N, P1, P2 ] S: udvegaḥ syāt; D, I, L1, Penn: udvejitavyam. samsārāraṇyataḥ, C, D, F, H, I, K (kha), L1, N, P1, Penn, S ] P2: samisārāraṇyaḥtaḥ; K (ka): samisārāvāsataḥ; L2: samsāāạnyavah sudhiyā, C, D, F, H, K, L1, L2, N, P1, P2, Penn ] I, S: sudhiyah

To whom do even the gods offer profound respect? To one who whose chief goal is compassion (55).

From what should one shrink in fear? The wise one [shrinks in fear] from the wilderness of transmigration (56).

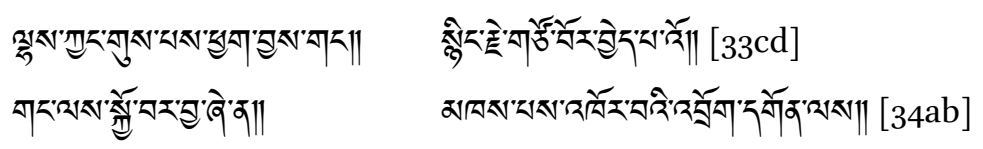

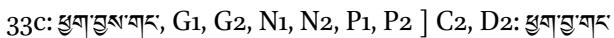

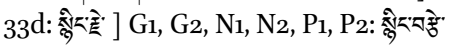

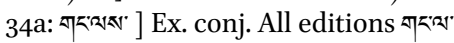




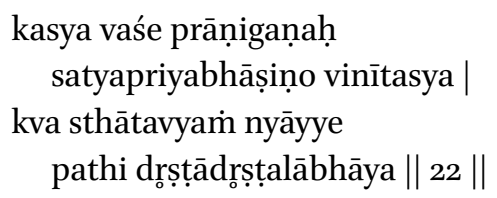

kasya vaśe, D, F, H, K, L2, P1, P2, S ] I, L1, Penn: kasya vaśāḥ; N: kasya vaśī?; C: kasya vaśah prāṇigaṇaḥ, C, F, H, K, L2, N, P1, P2, Penn, S ] D, I, L1: prāṇigaṇāḥ

satyapriyabhāṣiṇo, C, D, F, H, K, L2, N, P1, P2, S ] L1, Penn: satyapriyabhāṣaṇa; I: satyapriyabhāṣa

vinītasya, D, F, H, I, K, L1, L2, N, P1, P2, Penn, S ] C: vigamitasya

pathi, C, D, F, H, K, L2, N, P1, P2, S ] I, L1, Penn: pathi ca

drṣțādroșțalābhāya, D, F, I, K (ka), L2, P1, P2 ] S: droșțādrsșțalābhāḍhya; C, K (kha), L1, N, Penn: drsșțādrșțārthalābhāya (unmetrical); H (pc): drașțadrsțtilābhāya

To whom are people obedient? To one who speaks what is true and agreeable, and who is humble (57).

Where should one be fixed? On the right path, in order to obtain seen and unseen [benefits in this world and the next] (58).
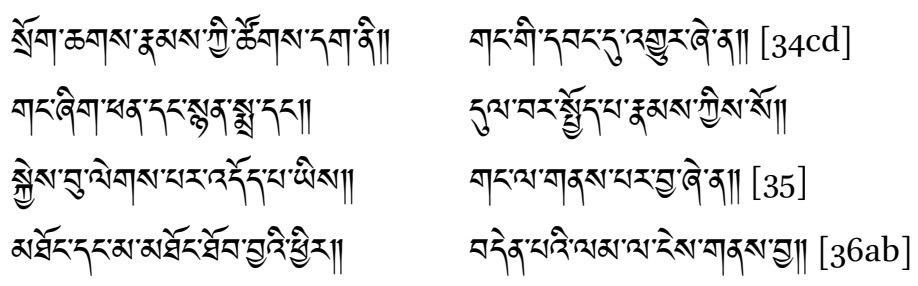

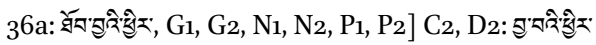

Tibetan renders the question in $\S 58$ "Where should a being who seeks to obtain the good ...." 


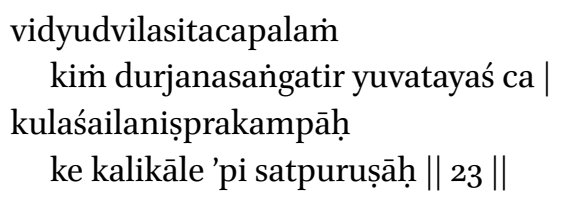

vidyudvilasitacapalam, C, F, H, K, L1, L2, N, P1, P2, Penn, S ] D: vidyudvilapitacapalamं; I: vidyudvilasitacalam

durjanasangatir, D, F, I, L1, Penn, S ] P1: durjjanam samgatamं; P2: sam்gatam durjana; H, K, $\mathrm{N}$ : durjanasamgatam; L2: durjahasamgatam; $\mathrm{C}$ : durjanasamgatiś ca kulaśailaniṣprakampāḥ, F, H, K, N, P2 ] C, D, I, L1, L2, P1, Penn, S: kulaśílaniṣprakampāḥ satpurușāh, C, D, F, H, I, K, L1, L2, N, P1, P2, Penn ] S: sajjanā eva

What is unsteady like a flash of lightnening? Association with bad people and young women (59).

Who are unshakable like enormous mountains? Those who are noble even in the degenerate Kali age (6o).

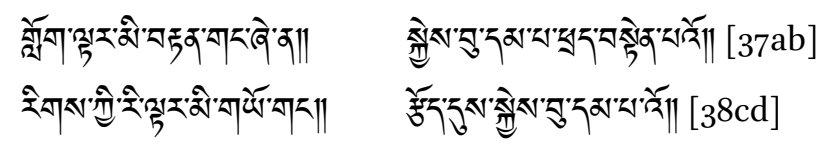

In $\S 59$, it is very odd that Tibetan has "association with good persons" (noted also by Kanakura 1935:440). It is hard to imagine what the translators read, but perhaps (unmetrically) sujana ${ }^{\circ}$ in place of durjana ${ }^{\circ}$ ? However, the absence of any equivalent for yuvatayaś $c a$ suggests that their Vorlage may have had an entirely different line here. Note that skyes bu dam pa appears immediately below this in $38 \mathrm{~d}$, where it renders satpurușa. In §6o, instead of "Kali age" one might understand "time of conflict." Kula is understood literally in Tibetan with rigs. It would perhaps make better sense to take kalikāle 'pi with the question, but the Tibetan translation clearly takes it with the answer. 


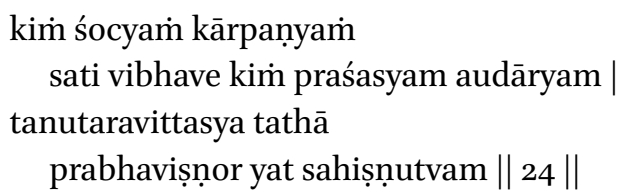

Verse absent in C, D; see below for cd in I, L1, Penn, S śocyam, F, H, I, K, L1, P1, S ] P2: śocya; Penn: śācyam;; L2, N: śaucyam kārpaṇyam, F, H, I, K, L2, N, P2, Penn ] L1, P1: kāryyaṇyam

kim praśasyam audāryam, F, H, I, K, L2, N, P2 ] L1, Penn, S: kim praśastam audāryam்; P1: ki praśasyam audāryyam

tanutaravittasya $\mathrm{H}, \mathrm{K}, \mathrm{N}, \mathrm{P}$, P2 ] F: na tu gatavittasya (W emends: nanu gatavittasya); L2 tanv ataravittasya

prabhaviṣnor yat sahiṣnutvam, F, H, K, N ] P1: prabhavișmor yat sahișmutvamं; L2, P2: prabhuviṣnor yat sahiṣnutvam

What is deplorable? Niggardliness when one is wealthy (61). What is praiseworthy? The magnamimity

of one who has very little wealth, and likewise the forebearance of one who is powerful (62).
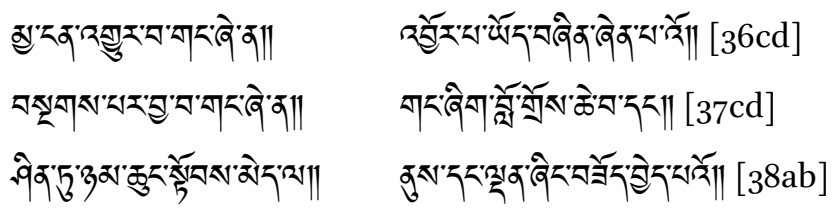

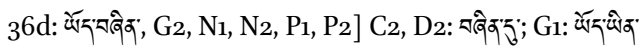

In I, L1, Penn, S, this verse comes below verse 26. They read cd as:

kaḥ pūjyo vidvadbhị̣ svabhāvataḥ sarvadā vinīto yạ̣

sarvadā, S] Penn: sarvathā; I: sarvațhā; Lı: sadā

Who should be honored by the wise? One who is by nature always/in every respect humble.

Kanakura 1935: 440 has commented at length on this verse. See Appendix 1 for the continuation of verses in I, L1 and Penn. 


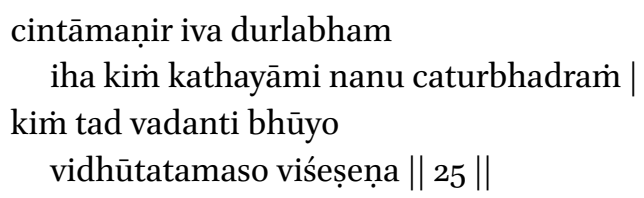

Omitted in N. Feet cd absent in C, D. cintāmaṇir, D, F, H, I, K, L1, L2, P1, P2, Penn, S ] C: maṇir durlabham iha, D, F, H, I, K, L1, L2, P1, Penn, S ] P2: durllabham; C: satatam kim kathayāmi, C, F, H, I, K, L1, L2, P1, Penn, S ] P2: kim iha kathayāmi; D: kim kathaye nanu, F, H, K, L2, P1, P2 ] S: tac; C, I, Penn: ø; L1: te; D: written and cancelled kim tad vadanti, F, H, K, L2, S ] P2: kim tad vadati; I, L1, Penn: kim tad vadeti; P1: etad vadanti

vidhūtatamaso, H, I, K, L1, L2, P1, Penn (pc), S ] F: 'vidhutamanaso (W: for metre 'vidhūtamanaso); $\mathrm{P}_{2}$ : vidhutam tamaso

What is rare here [in the world] like a wish-fulfilling gem? I will tell you: surely the four good things.

What are they? Those who have shaken off ignorance speak of these again and again in distinguishing them:

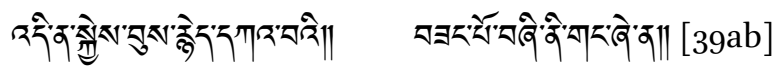

Tibetan has no equivalent to $25 \mathrm{~cd}$, and the text proceeds directly to the answer in the next verse. As we saw above with Tibetan verse 19, however, some portion of the original was already lost to the version enshrined in the Tanjurs, so the absence of the line here does not necessarily provide evidence for an original absence from the translation produced by Kamalagupta and Rin chen bzang po. The text, however, is coherent without the missing passage. Note that Weber, who emended the text, understood it rather as: "Nun, und was nennen denn speciell so die, deren Sinn unerschüttert ist." 


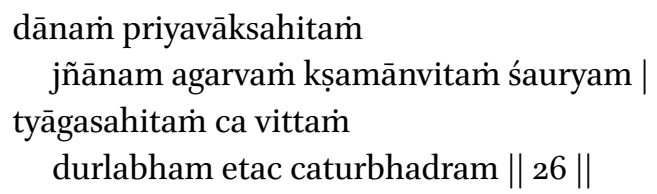

kṣamānvitamं, F, H, I, K, L1, L2, N, P1, P2, Penn, S ] D: kṣamāyuntam; C: kṣamāyutam tyāgasahitam ca vittam, $\mathrm{H}, \mathrm{K}, \mathrm{N}, \mathrm{P} 1]$ L2: tyāgasahitam ca cittam; $\mathrm{P} 2$ : tyāgasahitam ca vittam ca; C, F, S: vittam tyāgasametam; D: vittam tyāgasametam eavittam; I, L1, Penn: tyāgasametam vittam

Charity, accompanied by affectionate speech; knowledge free of pride; valor linked with patience;

and wealth accompanied by generosity — these four good things are rare (64).

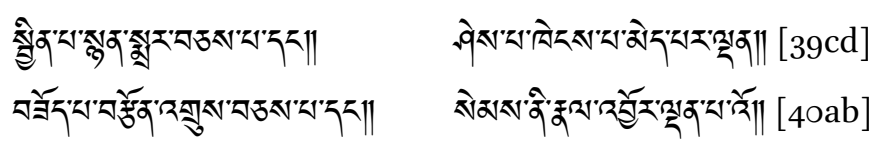

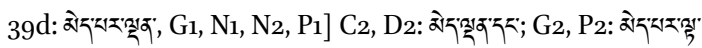

This verse is precisely Hitopadeśa I.156. The Tibetan translation of Sanskrit 26c is discussed in the Introduction, above.

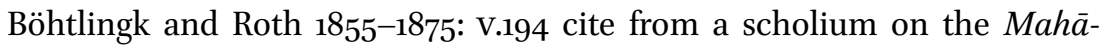
bhärata (their reference 7.2182, evidently to the Calcutta edition, to which I do not have access) the following verse:

vittam dānasametamiñ̄ānam agarvaṁ kṣamānvitam śauryam | bhogah sangavihino durlabham etac caturbhadram \|

The category of caturbhadra is extremely flexible, or rather, the term is used to refer to a variety of elements. Here we have dāna, jñāna, śaurya (kșamāa), vitta (tyāga). As Lindtner 1999: 121-122 mentions, in Nāgārjuna's Ratnāvalī the four are satya, tyāga, upaśama and prajñā. However, the Mahābhārata provides lists including: kìrti, āyus, yaśas and bala; dharma, jñāna, vairāgya and aiśvarya; dharma, artha, kāma and bala. ${ }^{62}$ For the present, perhaps it suffices to say

62 Unfortunately Lindtner's idiosyncratic article does not really further explore these categories. 
that the category caturbhadra is a box into which a wide variety of items may be placed.

Following this verse $\mathrm{P}_{2}$ has: yugmam, indicating that this verse is to be read together with the preceding verse 26 .

iti kaṇthagatā vimalā

praśnottararatnamālikā yeșām |

te muktābharaṇā iva

vibhānti vidvatsamājeșu || 27 ||

Absent in C, D. In S this is verse 67. Before this verse, $\mathrm{N}$ has two additional verses, for which see below Appendix 2.

iti kaṇṭhagatā vimalā, I, K, L1, P2, Penn ] S: ity eșā kaṇṭhasthā; F, H, L2, P1: iti kaṃṭhagatā vimala; $\mathrm{N}$ : iti kaṇthasthitavimala

te muktābharaṇā iva, S ] F, H, K, L2, P2: te muktābharaṇā api; P1: te muktābharaṇa api; L1, Penn: te muktāmaraṇād api; I: te muktābhāraṇād

vibhānti vidvatsamājeșu, F, H, I, K, L1, L2, P1, P2, Penn ] S: vimalāś cābhānti satsamājeṣu; $\mathrm{N}$ : vibhanti vidvatsamājeșu

Those who memorize this immaculate small precious garland of questions and answers, keeping it like a precious garland around their necks,

will shine among the crowds of the learned as if wearing pearl necklaces.

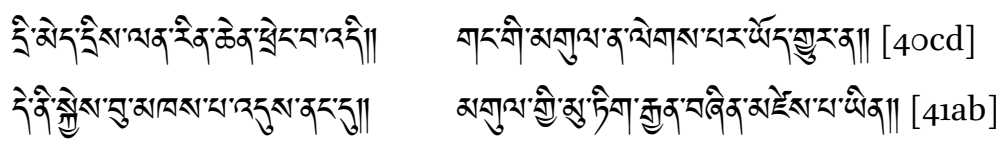

In c, the reading $i v a$ is supported by Tibetan $b z h i n$, while api is regularly rendered in Tibetan with kyang. If we read api, we might also understand (taking mukta as a participle rather than muktā as pearl): "even having dropped their ornaments". Perhaps both senses were intended. Note that here again, as with the first verse, Tibetan has chosen a longer metre of 9 syllables per foot. 


\section{Appendices}

A1 Extra Verses in I, L1 and Penn, Partially Corresponding to Verses in S Although I give the verses as found in the sources, there is evidently an error in organization, since the metre indicates that the ab feet and the cd feet have somehow been reversed, and perhaps one line at the beginning of the sequence has been lost. Moreover, in some places the metre is problematic and it has not been possible to restore the lines satisfactorily.

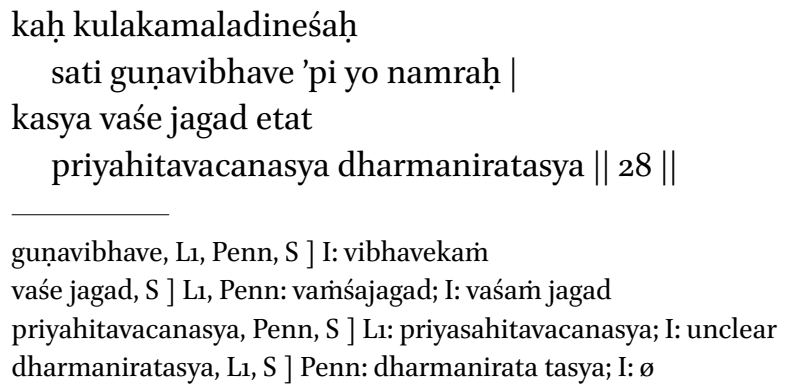

Who is the sun shining on the lotus-flower of his family? One who is humble, even though he is endowed with virtues and wealth.

To whom is everyone in the world obedient? To one whose speech is sweet and beneficial, and who is devoted to the Dharma. [28]

paradhanahrdayaharā kā satkavitā vivekavanitā ca | kam̉ na sprśati vipattir vroddhavacanānuvartinam dāntam || 29 ||

paradhanahrọdayaharā kā satkavitā vivekavanitā ca, I, L1 ] Penn: paradhanahridaharā kā satkavitā vivekavanitā ca; S: vidvanmanoharā kā satkavitā bodhavanitā ca

sprśati, I, Lı, S ] Penn: sprśāāi

vroddhavacanānuvartinam ] Ex. conj: I, L1 (pc), Penn: vróddhavacanonuvarttinam;; S: pravṛddhavacanānuvartinam;

dāntam, S ] I, Lı: dātaram; Penn: dātāram

What captures the wealth and the hearts of others? Good poetry and a discerning woman.

Whom does misfortune not touch? One [self-]controlled who follows the guidance of the elders. [29] 


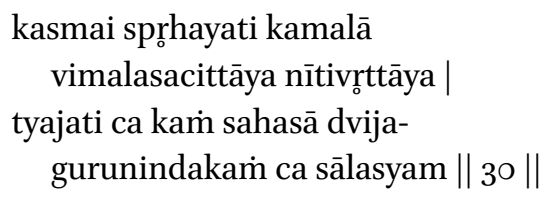

vimalasacittāya, I, Penn ] Lı: vimalasaccaritāya; S: tv analasacittāya sahasā, Penn, S ] I: sahasām; Lı: sahasā sā dvijagurunindakam, I, L1, Penn ] S: dvijagurusuranindākaram

Whom does Lakșmī envy? One with a pure mind, whose conduct is proper.

And whom does [she] suddenly abandon? One who finds fault with brahmins and gurus, and is slothful. [30]

kutra vidheyo vāsah

sajjananikațe 'thavā kāśyām |

kaḥ parihāryo deśạ piśunayuto lubdhabhūpaś ca || 31 ||

ab in D 16ab.

parihāryo, L1, Penn, S ] I: parihāro

piśunayuto, I, S ] Lı: pișyunayuto; Penn: piśunayutā

Where ought one to have one's residence? Nearby to good persons, or alternatively, in Varanasi.

What location is to be avoided? One filled with slanderers, and [one ruled by] a greedy king. [31]

kenāśocyah puruṣạ praṇatakalatreṇa dhīravibhavena |

iha bhuvane kah śocyah saty api vibhave na yo dātā || $3^{2}$ \|

kenāśocyah, I, Penn, S ] L1: kim nāśocyam

How does a person become unpitiable? By means of a humble wife and lasting wealth.

Who is pitiable here in this world? One who is not a giver despite having wealth. [32] 


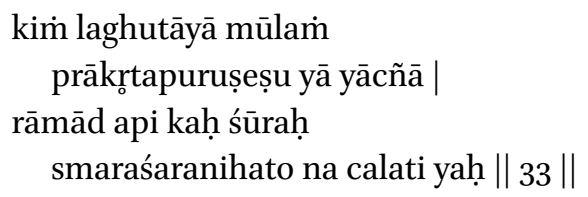

laghutāyā, I, L1, S ] Penn: ghutāyā

calati yah, I, Lı, Penn ] S: yaś calati

What is the source of contempt? Begging from vulgar persons.

Who is a greater hero even than Rāma? One who, struck by Cupid's arrows, is not affected. [33]

kim aharniśam anucintyam

keśavacaraṇau jagaccalatā |

kā ca sabhā parihāryā

hīnā yā vrơddhasacivena || 34 ||

After $34 \mathrm{~b}$ is entirely different in S, which then has our $34 \mathrm{~cd}$ as its $37 \mathrm{ab}$; b is difficult to decipher in I, and might read differently

jagaccalatā ] I: ?gaccambalatā; L1, Penn: jagaccamicalatā

What should one contemplate day and night? The feet of Krṣna and the unsteadiness of the world.

And what assembly is to be avoided? One which is lacking in any senior member. [34]

brūhi sphurati ca kā vā

svabhyastā nirmalā vidyā |

prānāa api ko rakṣyah

kuladharmaḥ sādhusamigaś ca || 35 ||

$35 \mathrm{ab}$ (very difficult to decipher in I): S: ø; $35 \mathrm{~cd}=\mathrm{S}_{3} 8 \mathrm{ab}$

And tell me, what else shines forth? Spotless knowledge which has been well-rehearsed.

What is to be defended even at the cost of life? One's family duty and contact with the good. [35] 


\section{A2 Extra Verses in N}

sarvasvāvadhidānam

niravadhikaruṇā ca janmāvadhidhairyam |

iti yo leḍhi triphalām

na tasya samisārikā rogāḥ || 25

niravadhikaruṇa ] N: niradhikaruṇā

triphalām ] N: t[r]iphalān

The one who tastes the medicine consisting of three fruits-giving everything, even oneself, endless compassion and life-long fortitude-is not subject to the illness of transmigration.

A metrical problem remains in foot $\mathrm{b}$. The three fruits (triphalā) are haritaki (Chebulic myrobalan, Terminalia chebula Retz.), vibhitaka (Belleric myrobalan, Terminalia bellerica [Gaertn.] Roxb.) and àmalaka (Indian gooseberry, Emblica officinalis = Phyllanthus emblica Linn.). The verse redefines these remedies as medicines for another kind of illness, that of samiāra itself.

ko dharmo bhūtadayā

kim saukhyam arogitā jantoh |

kaḥ snehạ̣ sadbhāvaḥ

kim pāṇḍityam paricchedạ || 26 [metre upagìti]

What is the Dharma? Compassion toward beings. What is felicity? The health of beings.

What is affection? A good disposition. What is erudition? Discrimination.

A3 Additional Readings from Tanjur Editions of the Tibetan Translation

$1 a$

$1 \mathrm{~b}$ dri med dris lan] G1, N1, P1: dri med dri lan

phreng ba 'di ] G1, N1, P1: phreng ba ni

nges par ] $\mathrm{C}_{2}$ : ngas par

gnas gyur na ] G2, N2, P2: gnas 'gyur na

ma mthong sgrub pa ] G2, N2, P2: ma mthong bsgrub pa

rgyan du 'gyur ba ] G1, G2, N1, N2, P1, P2: rgyan du gyur ba

bla ma'i ] G1, N1: blang pa'i

ring bya ] N2: rig bya 


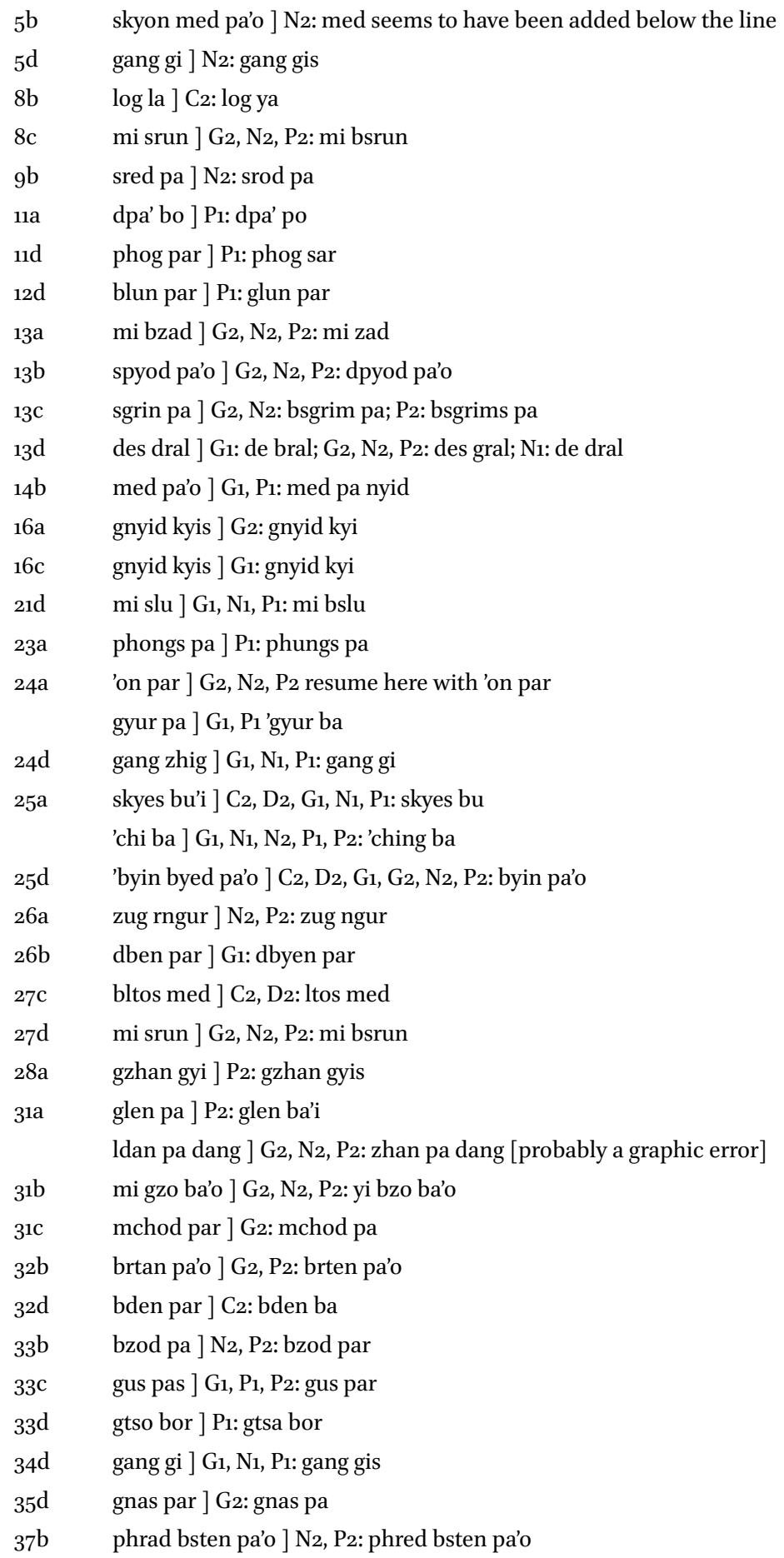




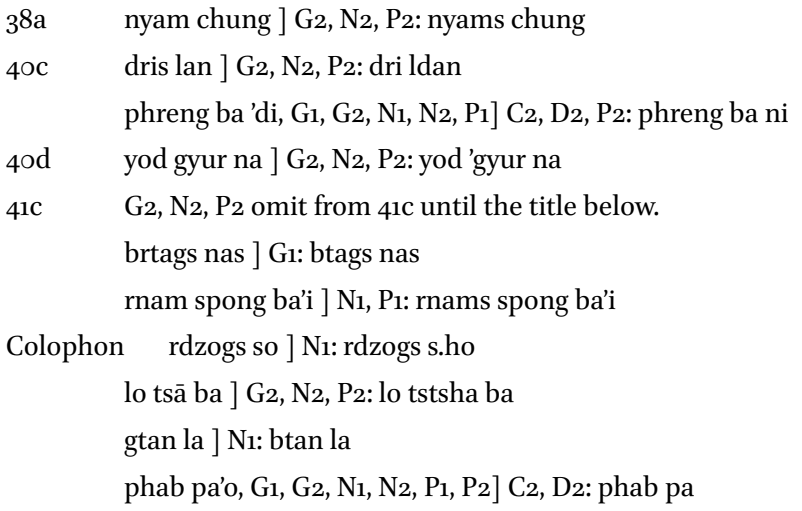

\section{References}

Āchārya, Nārāyạ̣ Rām. 1952. Subhāṣitaratnabhāṇdāgāra, or Gems of Sanskrit Poetry, being A Collection of witty, Epigrammatic, Instructive and Descriptive verses, with their sources. Eighth edition. Bombay: Nirnaya Sagar Press

Anon. 1910. The Works of Sri Sankaracharya. Vol. 16. Srirangam: Sri Vani Vilas Press.

Aufrecht, Theodor. 1892. Florentine Sanskrit Manuscripts. Leipzig: G. Kreysing.

Barnett, L.D. 1928. A supplementary Catalogue of the Sanskrit, Pali, and Prakrit Books in the Library of the British Museum acquired during the years 1906-1928. London: British Museum.

Beckh, Hermann. 1907. Die tibetische Übersetzung von Kälidāsa’s Meghadūta. Berlin: Verlag der Königl. Akademie der Wissenschaften.

Bendall, Cecil. 1902. Catalogue of the Sanskrit Manuscripts in the British Museum. London: The British Museum.

Bhagavat, Hari Raghunath. 1952. Minor Works of Śrī Śankkarācārya. 2nd ed. Poona Oriental Series 8. Poona: Oriental Book Agency. [text 13]

Bhandarkar, Ramkrishna Gopal. 1887. "Report on the Search For Sanskrit Manuscripts In the Bombay Presidency during the year $1883^{-84 . "}$

Bhandarkar, Ramkrishna Gopal. 1895. Early History of the Dekkan:Down to the Mahomedan Conquest. Second edition. Bombay: Government Central Press.

Bhattacarya, Vidhushekhara. 1929. “Praśnottraratnamālikā.” Indian Historical Quarterly $5: 143^{-144 .}$

Böhtlingk, Otto and Rudolph Roth. 1855-1875. Sanskrit-Wörterbuch. St. Petersburg: Kaiserlichen Akademie der Wissenschaften.

Cabaton, A. 1907. Catalogue sommaire des manuscrits Sanscrits et Pālis. Paris: Ernest Leroux.

Christian, J[ohn]. 1847. "Prashnotaramálá, or Catechetical Dialogue of Sook." Journal of the Asiatic Society of Bengal 16/2: 1228-1235. 
Cordier, Palmyr. 1915. Catalogue du Fonds Tibétain de la Bibliothèque Nationale. Part 3. Paris: Imprimerie Nationale.

Dalāl, C.D. 1923. A Catalogue of Manuscripts in the Jaina Bhandars at Jesalmere. Ed. by Lālchandra Bhagawāndās Gāndhi. Gaekwad's Oriental Series 21. Baroda: Central Library.

Duff, C. Mabel. 1899. The Chronology of India from the Earliest Times to the Beginning of the Sixteenth Century. Westminster: Archibald Constable \& Co.

Durgâprasâd, Paṇdit, and Kâs'înâth Pândurang Parab. 189o. Kâryamâlâ: A collection of old and rare Sanskrit Kâryyas, Nâtakas, Champûs, Bhânas, Prahasanas, Chhandas, Alankâras \&cc. Bombay: Nirnaya-sâgara Press.

Filliozat, Jean. 1936. "Etat des manuscrits de la collection Émile Senart." Journal Asiatique 228: 127-143.

Fleet, John Faithful. 1883. "Sanskrit and Old-Canarese Inscriptions." Indian Antiquary 12: $215^{-225}$.

Fleet, John Faithful. 1891. "A note on Amoghavarsha I." Indian Antiquary 20: 113-114.

Flügel, Peter, \& Kornelius Krümpelmann, eds. 2016. Jaina-Onomasticon by Johannes Klatt. Jaina Studies 1. Wiesbaden: Harrassowitz.

Foucaux, Philippe-Edouard. 1867. "La guirlande précieuse." Mémoires de l'Académie des Stanislas:54-8o. Expanded in La guirlande précieuse des demandes et réponses; publiée en Sanskrit et en Tibétain et traduit pour la première fois en Français. Paris: Maisonneuve et Cie, 1867 .

Gāndhī, Lālcandra Bhagavāndās. 1949. "Praśnottararatnamālā kā kartā?” In Khuśalcandra Gorāvālā, ed. Varni Abhinandan Granth. Sāgar: Śrī Varṇī Hīrak Jayantī Mahotsav Samiti: 419-422.

Gangnegi, Hira Paul. 1998. "A Critical Note on the Biographies of Lo chen Rin chen bZang po." The Tibet Journal 23/1: 38-48.

Garrez, Pierre-Gustave. 1867. Rev. of Foucaux 1867. Journal Asiatique Sér. 6, t. 10: 502510 .

Hahn, Michael. 1985. "Die indischen Nītiśātras im tibetischen Tanjur." Zeitschrift der Deutschen Morgenländischen Gesellschaft. Supplement vi: 227-237.

Hahn, Michael. 2007. "Ravigupta and his Nīti Stanzas (I)." Minami Ajia Kotengaku (南 アジア古典学 = South Asian Classical Studies) 2:303-355.

Hahn, Michael. 2008. "Ravigupta and his Nīti Stanzas (II)." Minami Ajia Kotengaku (南 アジア古典学 = South Asian Classical Studies) 3: 1-38.

Hahn, Michael. 2009. "The Tibetan Shes rabs dong bu and its Indian Sources." Minami Ajia Kotengaku (南アジア古典学 = South Asian Classical Studies) 4: 1-78.

Hahn, Michael. 2012. "Vararuci's Gāthāśataka (Tshigs su bcad pa brgya pa) and its Indian Sources." Minami Ajia Kotengaku (南アジア古典学 = South Asian Classical Studies) 7: 367-458.

Jacobi, Hermann, \& Muni Shri Punyavijayaji. 1962. Ācārya Vimalasūri’s Paümacariyam, Part I. Prakrit Text Society Series 6. Varanasi: Prakrit Text Society. 
Janert, Klaus Ludwig, and Narayanan Narasimhan Poti. 1975. Indische und Nepalische Handschriften 4. Verzeichnis der orientalischen Handschriften in Deutschland II.4. Wiesbaden: Franz Steiner Verlag.

Kanakura Enshō (金倉圓照). 1935. "Baramonkyō Jinakyō Bukkyō kōshō no ichijirei: Mondō hōman ge no kenkyū oyobi honyaku” (波羅門教。者那教。佛教交涉の一 事例: 「問答寶輷」偈の研究及僠譯). Tōhoku Teikoku Daigaku hōbungakubu (東 北帝國大學法文學部) ed., Testugaku Ronshū Jusshūnen kinen (哲學論集十周年記 念). Tokyo: Iwanami shoten (岩波書店): 350-399. Reprint in Indo Seishin Bunka no Kenkyū: toku ni Jyaina o chüshin to shite (印度精神文化の研究特にジャイナを中心 として). Tokyo: Baifukan (倍風館), 1944: 397-459. I refer to the latter.

Kennedy, John McFarland. 1913. The Satakas: Or, Wise Sayings of Bhartrihari. Literature and philosophy of the Orient 1 London: T. Werner Laurie, Ltd.

Kosambi, D.D. [Damodar]. 2000. The Epigrams Attribted to Bhartrhari. 2nd ed. New Delhi: Munshiram Manoharlal.

Lindtner, Christian. 1999. "What is the Dharmaś Caturbhadrah?" Indo-Iranian Journal 42: 121-140.

Martin, Dan. 2008. "Veil of Kashmir-Poetry of Travel and Travail in Zhangzhungpa's 15th-Century Kāvya Reworking of the Biography of the Great Translator Rinchen Zangpo (958-1055 CE)." Revue d'Etudes Tibétaines 14: 13-56.

Mironov, Nikolaj Dmitrievič. 1918. Katalog indijskix rukopisej Rossijskoj publičnoj biblioteki. Sobranie I.P. Minaeva i někotoryja drugija. Vypusk I. Petrograd: Izdanie Rossijskoj akademii nauk. (Миронов, Николай Дмитриевич. Каталогъ индійскихъ рукописей Россі̄йской публичной библі̄отеки. собрані̄е И.П. Минаева и нБкоторыя другя. Петроградъ: Изд. Россїйской академі̄и наукъ.)

Nolot, Édit. 1997. "The Script of the Mahāsāmghika-Lokottaravādin Bhikṣuṇī-Vinaya and Abhisamācārikā Dharmāḥ Manuscript from the R. Sānkkrtyāyana Collection." In Heinz Bechert, Sven Bretfeld and Petra Kieffer-Pülz, eds., Untersuchungen zur buddhistischen Literatur: Zweite Folge. Gustav Roth zum 80. Geburtstag gewidmet. Sanskrit-Wörterbuch der buddhistischen texte aus den Turfan-Funden Beiheft 8. Göttingen: Vandenhoeck \& Ruprecht: $267-272$.

Pathak, K[ashinath] B[apuji]. 1902. "Nripatunga's Kavirâjamârga.” The Journal of the Bombay Branch of the Royal Asiatic Society 20: 22-39.

Pathak, S[uniti] K[umar]. 1958a. "Vimala-praśnottara-ratnamālā." Journal of the Greater India Society 17/1-2: 92-113.

Pathak, Sunitikumar. 1958b. “Cānakyarājanītiśāstram." Visva-BharatiAnnals 8 (separate pagination).

Pathak, Sunitikumar. 1961. "Nītiśāstra of Masūrākșa." Visva-Bharati Annals 10 (separate pagination).

Pathak, Suniti Kumar. 1974. The Indian Nitisastras in Tibet. Delhi: MotilalBanarsidass. 
Pavolini, Paolo Emilio. 1898. “Una redazione pracrita della Praçnottararalnamãlā." Giornale Della Società Asiatica Italiana 11: 153-163.

Pavolini, Paolo Emilio. 1907. "I manoscritti indiani della Biblioteca Nazionale Centrale di Firenze (non compresi nel catalogo dell'Aufrecht)" Giornale della Società asiatica Italiana 20: $63^{-157 .}$

Peterson, Peter. 1883. Detailed Report of Operations in Search of Sanskrit Mss. in the Bombay Circle August 1882-March 1883. Extra Number of the Journal of the Bombay Branch of the Royal Asiatic Society. Bombay: Society's Library, Town Hall/London: Trübner \& Co.

Peterson, Peter. 1887. "A Third Report of Operations in Search of Sanskrit Mss. in the Bombay Circle April 1884-March 1886." Extra Number of the Journal of the Bombay Branch of the Royal Asiatic Society. Bombay: Society's Library, Town Hall/London: Trübner \& Co.

Peterson, Peter. 1888. The Paddhati of Sarngadhara. A Sanskrit Anthology. Vol. I: The Text (all published). Bombay Sanskrit Series 37. Bombay: Government Central Book Depot.

Poleman, H.I. 1938. A census of Indic manuscripts in the United States and Canada. New Haven, Conn: American Oriental Society.

Sastri, Haridas. 189o. "Miscellanea: A Note on Vimala." The Indian Antiquary 19: 37838 o.

Schiefner, Anton. 1858. Carminis indici "Vimalapraçnottararatnamālā" versio tibetica. Petropoli: Typis Academicis. Academiae Jenensi Saecularia tertia diebus xv, xvi, xvii Aug. anni mDccclviI celebranda gratulatur Academia Caesarea scientiarum Petropolitana.

Schubring, Walther. 1944. Der Jaina-Handschriften der Preussischen Staatsbibliothek. Verzeichnis der handschriften im Deutschen Reich. 3: Die Handschriften der preussischen Staatsbibliothek, 1: Die orientalischen Handschriften. Leipzig: Otto Harrassowitz.

Seyfort Ruegg, David. 1995. Ordre spirituel et ordre temporel dans la pensée Bouddhique de l'Inde et du Tibet. Quatre conférences au Collège de France. Publications de l'Institut de Civilisation Indienne, Série in-80, Fasc. 64. Paris: Boccard.

Sørensen, Per K. 1994. Tibetan Buddhist Historiography: The Mirror Illuminating the Royal Genealogies: An Annotated Translation of the XIvth Century Tibetan Chronicle: rGyal-rabs gsal-ba'i me-long. Asiatische Forschungen 128. Wiesbaden: Harrassowtiz Verlag.

Sternbach, Ludwik. 1961. "The Tibetan Cāṇakya-rāja-nīti-śāstram.” Annals of the Bhandarkar Oriental Research Institute 42: 99-122.

Sternbach, Ludwik. 1962. Review of Pathak 1961. Journal of the American Oriental Society 82/3: 407-411.

Takeuchi, Tsuguhito and Iuchi Maho. 2016. Tibetan Texts from Khara-khoto in The Stein 
Collection of the British Library. Studies in Old Tibetan Texts from Central Asia 2; Studia Tibetica 48. Tokyo: The Toyo Bunko.

Torricelli, Fabrizio. 1993. "Praśnottararatnamālā, la preziosa ghirlanda di domande e risposte." In forma di parole (third series) 1/1: 9-30.

Veezhinathan, N., C.S. Sundaram and N. Gangadharan. 1988. New Catalogus Catalogorum: An Alphabetical Register of Sanskrit and Allied Works and Authors. Vol. 12. Madras University Sanskrit Series 38. Madras: University of Madras.

Velankar, Hari Damodar. 1944. Jinaratnakośa: An alphabetical register ofJaina works and authors. Vol. I. Works. Government Oriental Series Class C No. 4. Poona: Bhandarkar Oriental Research Institute.

Vimalabodhi Vijayaju, ed. 2005. Praśnottara ratnamālā. Mumbai: АвC Publications.

Weber, Albrecht. 1868. "Über die Praçnottararatnamâlâ, Juwelenkranz der Fragen und Antworten." Monatsberichte der Königlich Preussischen Akademie der Wissenschaften zu Berlin: 92-117. Reprint in Indische Streifen I. Berlin: Nicolaische Verlagsbuchhandlung, 1868: 210-227.

Weber, Albrecht. 1891. Verzeichniss der Sanskrt-un Prakrt-Handschriften der Königlichen Bibliothek zu Berlin. II/3. Die Handschriften-Verzeichnisse der Königlichen Bibliothek zu Berlin. 5. Berlin: A Asher \& Co.

Wilson, Horace Hayman. 1832. "Sketch of the Religious Sects of the Hindus." Asiatic Researches: or, Transactions of the Society, Instituted in Bengal, for enquiring into the History, the Antiquities, the Arts and Sciences, and Literature of Asia 17: 169-313. 